\title{
Development of a fuel efficient cookstove through a participatory bottom-up approach
}

\author{
Vijay H Honkalaskar ${ }^{1}$, Upendra V Bhandarkar ${ }^{2 *}$ and Milind Sohoni ${ }^{3}$
}

\begin{abstract}
Background: Since 1940s, other than a few success stories, the outcomes of efforts of development and dissemination of improved cookstoves ${ }^{\text {a }}$ have not been so fruitful. This paper presents a bottom-up approach that was successfully implemented to develop a fuel-efficient cookstove in a tribal village that has resulted in a substantial reduction in firewood consumption.

Method: The approach ensured people's participation at multiple stages of the process that started from project selection by capturing people's needs/desires and studying the existing cooking practice to understand its importance in the local context. The performance of the cookstoves was evaluated by modifying a standard Water Boiling Test to accommodate the existing cooking practice. The improvement of the cookstove was achieved by fabricating a simple twisted tape assembly that could be placed on it without changing the existing cookstove.

Results: The optimization of the twisted tape device was first carried out in the laboratory and then implemented in the field. The field-level tests resulted in reduction of firewood consumption by around $21 \%$ which is a substantial improvement for such a device. It was also found that the improvement reduced soot ${ }^{\mathrm{b}}$ accumulation by around $38 \%$ and time of cooking preparations by around $18.5 \%$.

Conclusion: Overall, a bottom-up and participatory process that not only addressed people's perceived needs but also ensured no changes in the existing cooking practice while providing an easy, low cost (around US\$1.25) ${ }^{\mathrm{c}}$, and locally manufacturable solution led to a highly successful improvement in the local cookstove that was accepted easily by the villagers.
\end{abstract}

Keywords: Improved cookstove; Bottom-up approach; Twisted tapes; People's participation

\section{Background}

The inception of a development discourse in the West around the 1940s [1] has led to development of new technologies to address the problems of the poor in undeveloped and developing countries. Since then, the development and dissemination of improved cookstoves has been one of the key areas for development practitioners in government, volunteer organizations, and research laboratories $[2,3]$. Other than a few success stories, the outcomes of efforts of these practitioners have not been so fruitful. This section summarizes impacts

\footnotetext{
*Correspondence: bhandarkar@iitb.ac.in

${ }^{2}$ Department of Mechanical Engineering, Indian Institute of Technology

Bombay, Powai, Mumbai, 400076, India

Full list of author information is available at the end of the article
}

and challenges of different improved cookstove programs over the past 50 years. Sesan [4] broadly categorized these programs in three phases. We have adopted this categorization in the present context of technology development. These three phases are enumerated below.

\section{Early programs (1950 to 1980)}

Since the 1950s, the development and dissemination of improved cookstoves in the developing countries [3] was, to a large extent, due to initiatives from western countries. According to Crewe [5], fashionable aims such as 'working with poor women', 'raising the income of poor artisans', and 'conserving environmental resources' promoted the involvement of international organizations in the development of improved cookstoves. The main goal of this phase for improved cookstoves was to increase

\section{Springer}

(C) 2013 Honkalaskar et al: licensee Springer. This is an Open Access article distributed under the terms of the Creative Commons Attribution License (http://creativecommons.org/licenses/by/2.0), which permits unrestricted use, distribution, and reproduction in any medium, provided the original work is properly cited. 
the thermal efficiency of the cooking process to reduce the envisaged energy gap [5] between the supply and demand of biomass fuel due to the thinning of the forests. These early programs assumed that people would adopt the improved stoves quickly and that an initial intervention would lead to a self-sustaining program. It was also assumed that there existed only a need to distribute improved cookstoves, and since these were intrinsically superior to the traditional cookstoves, a decrease in fuel consumption by $75 \%$ or even more was imminent [6]. As a consequence of these assumptions, the attempts in this phase failed. The clearest of the lessons learned from early experience is that the chances of success are enhanced when people have an explicit need to save fuel, when the new stoves are a significant improvement over the local traditional stoves, and when stoves can be made readily available by local industries or artisans at affordable prices.

\section{Context responsive phase (1980 to 1990)}

Researchers started to understand that there is a weak link between deforestation and traditional cookstoves as people cut only small branches to fire their cookstoves [6]. The main objective of the cookstove programs was changed to improve the efficiency of the cookstove to address the perceived needs of users to reduce drudgery involved in the firewood fetching activity. Reduction in indoor air pollution was a secondary objective. Researchers started to emphasize the involvement of local people in the cookstove programs. Yet, these programs faced significant problems in gaining the acceptance of the rural poor [6]. There have been a few partial success stories, mainly in urban areas where fuel has to be bought, and hence, cookstove programs became economical. These include 'Jiko' and 'Upesi' stoves in Kenya [7], Chinese national stoves program [8], 'Anagi' stoves in Sri Lanka, and 'Sara-ole' stove in Karnataka, India [9]. There were two nationwide programs implemented by India and China that followed two different dissemination routes. The Indian National Program on Improved Cookstoves (NPIC) was started in 1983. More than 2.8 million stoves were disseminated until the year 2002 when the government of India officially withdrew funding support from the NPIC. The dissemination of the improved cookstoves was supported by government subsidies. Although it had a high dissemination number, NPIC is not recognized as a successful program because of a very low acceptance rate by users [10-12]. The Chinese National Improved Stoves Programme (NISP), which followed a market-based approach, disseminated 129 million stoves from 1982 to 1992 covering 65\% of the Chinese rural population. Most of the cost of stove material and construction labor was paid by the users. However, it must be noted that during this period, NISP operated in relatively middle income areas, and its benefit did not reach the rural poor at that time [8]. The more selfsustaining market-based approach adopted by NISP has led the international government and non-government agencies to follow a market-based approach in the third phase [13].

\section{Third phase (1990 onwards): market-based approaches}

The focus of improved cookstove programs for this phase has been to reduce indoor air pollution along with increasing cookstove efficiency [4]. Indoor air pollution caused by smoke from traditional cookstoves is responsible for nearly $4.3 \%$ of the total global diseases and causes more than 1.6 million deaths each year [14]. Drawing on the experience of the second phase, the market approach was emphasized [13]. For example, in India, there was an emergence of multiple stove designs and dissemination programs funded by private agencies. These involved Shell foundation, Envirofit International, Prakti Design, Selco India, B.P., and TIDE $[15,16]$. These have resulted in limited penetration, owing to high initial cost and low flexibility towards the use of local fuels $[11,16]$. Learning from these recent initiatives and outcomes of NPIC, the Indian government started the National Biomass Cookstove Initiative in 2009 [11,17], with the aim of providing energy service comparable to clean sources such as LPG while using the same solid biomass fuel with the combined objectives of fuel efficiency, health protection, and climate impacts. To ensure good quality control and reliable performance, this initiative lays an emphasis on centralized manufacturing facilities. There is narrower tolerance to biomass size and moisture content. Thus, there is an additional requirement of fuel processing at household level.

The Global Alliance for Clean Cookstoves was initiated in year 2010 [17]. Coordinated through United Nations Foundation, it has a goal of providing 100 million clean cookstoves by year 2020 which would reduce the health and other impacts of current cooking practices. In spite of all these efforts, what still remains is to make biomass stoves that are not only clean enough to have major health benefits but also affordable by the poor population of the world.

It can be noticed that most of the approaches adopted for improved cookstoves have remained top down and focused essentially on tangible technical objectives. Many researchers such as Bailis et al. [13] and Barnes et al. [6] acknowledge that although the market-based approach can achieve a sustainable dissemination model, it may filter out the poorer section of rural community. Nevertheless, most of these reports do not analyze the development and dissemination approach in the wider social, cultural, ecological, and economical context in which rural people construct their livelihoods. 


\section{Learning from the improved cookstove programs}

Goals and strategies to develop and disseminate improved cookstoves have changed over the three phases. These were based on the perceived needs/problems and perceived socio-economic context of community members. There have been a few success stories, where not only have the perceived needs and priorities of the community matched with reality, but this identification has been also followed by sustainable dissemination. Analysis of experiences of a number of (seven) improved cookstove programs around the world revealed the following facts:

(1) Community participation: It has been widely appreciated that people's participation is very crucial for the success of any development project. After the failure of the first round of improved cookstove projects until 1980, development agencies sought to adopt more participatory ways to develop and disseminate the improved cookstoves [18]. It is considered as vital for facilitating a detailed understanding of user needs and paramount for the success of any development program [19]. Involvement of the community takes care of local manufacture, suitability of improved cookstoves to the local cooking practices, and affordable cost $[7,20]$. However, even these participatory inputs from the user did not always reflect in a favorable outcome for many projects. The term 'participation' includes notions of people's empowerment, involvement, and control over the development initiative [21-23]. Agencies involved in improved cookstove projects usually have bureaucratic, power-conscious, performance-driven, and goal-oriented structures. It has been very difficult to appreciate people's empowerment and their control in the cookstove development project. Participatory methods adopted by these agencies have been criticized of preserving the participation in terms of mere appearance and actually adhering to a traditional top-down power relation [24]. The Kenyan biomass project in rural areas is an example of such failure of the participatory methods adopted by the Kenyan Ministry of Energy [18] along with donor agencies. Although the improved stove, 'Maendeleo', was very simple and made with locally available technology, not more than $4 \%$ of rural households adopted it. Energy saving was not the major concern of the rural dwellers owing to the freely and abundantly available firewood. However, the household income level of the people was very low, and they tended to stick with the traditional practice rather than buying a comparatively expensive (although the stove price was only around US\$1.5) alternative. Thus, all the remaining facts can be practically appreciated through people's participation by ensuring their involvement and control in every step.

(2) User priorities of needs: People tend to adopt interventions on the basis of what matters to them rather than the objectives of the improved cookstove program. The dominance of the interest of outsider stakeholders is one of the reasons of the failures of many improved cookstove programs [18,25]. Improved cookstove projects have been most successful in areas where firewood fetching is an arduous task or people have to spend a significant amount of money on purchasing wood [6]. In both these cases, improved stoves fulfill users' needs. Therefore, the goals of any cookstove program have to be decided on the basis of people's priorities which essentially vary with context.

(3) Study of existing practices: Cooking practice involves fuel type, fuel size, input power level, number of pots per cookstove, size of pots, time required to cook the food, and ease and flexibility of operation of cookstove. Cooking practices are deeply rooted in the society for hundreds of years [10]. Therefore, an improved cooking method that is different from existing practices has less appeal wherever the people using traditional cookstoves are bound to follow the existing practices because of economic, social, and religious constraints [26]. Therefore, it is imperative to design a new technology that suits the existing cooking practices and also seeks improvements in the performance. One of the reasons behind multiple failures faced by NPIC and a few market-based companies was that the proposed practice of improved stoves could not match the existing cooking practices carried by the community [10]. Notable examples are dissemination of portable stoves in Maharashtra [27] and Philips/BP-Oorja stoves that accommodate only a specific range of fuel type and size [16]. An improved cookstove should be similar to the traditional one to perform the existing cooking practices [7]. Understanding and accommodation of the users' practice to design an improved cookstove are very important for effective adoption and correct utilization of technology [28], even at the expense of not achieving the best efficiency [19,29].

(4) Other uses: Improved cookstoves do not usually cater to a few other uses and benefits that are sometimes derived from cookstoves such as lighting, space heating, reduction of insects and pests, and drying of thatched roof [30]. The design of improved cookstoves should take into account these characteristics of existing cookstoves. 
(5) Bridging the gap between laboratory and field: One of the most important reasons behind the failure of improved cookstove programs is not meeting the claim to save substantial amounts of fuel. In many cases, improved cookstoves are more efficient than the traditional ones under laboratory conditions, but their performance in field conditions is debatable because improved cookstove designs are found to be incompatible with traditional ways of cooking $[30,31]$. Oftentimes, the standard Water Boiling Tests (WBTs) are not indicative of the performance of cookstoves in rural communities [32]. This inadequacy can be attributed to lack of stove testing methods which take care of the existing cooking practices [33]. Therefore there, is a need to formulate a performance testing protocol by studying the existing cooking practice to reduce the gap between laboratory- and field-level outcomes.

(6) Commercialization and dissemination: In many successful programs, the stove dissemination has been an independent entrepreneurial activity. Entrepreneurs generally need technical assistance in designing the stoves and in marketing them to local people [6,29]. A well-designed promotion strategy involves informing the local people about the benefits associated with the improved stoves through a network of local volunteer organizations, television advertisements, or demonstration sites [20]. It is usually found that the local artisans or the trained people seldom adhere to the prescribed dimensions of an improved cookstove $[9,16,20]$. Thus, for local manufacturing of an improved cookstove, its operation should not be very sensitive to its dimensions.

Overall, it is imperative to understand people's needs and the existing practice to develop an improved cookstove that would be socially and economically acceptable. Improved cookstoves are most popular when they are easily and locally manufactured and have clear advantages in manufacturing cost, fuel economy, matching of existing cookstove practices, ease of use, and durability. Dissemination programs are most effective when they allow for interaction and feedback between stove designers, producers, and users.

Lessons of experiences of early cookstove programs led us to devise a novel approach to address a problem of drudgery involved in firewood fetching activity in a tribal village Gawand wadi (population 293), $120 \mathrm{~km}$ from Mumbai, located in Karjat Tribal Block of Raigadh District in the state of Maharashtra in western India (19 $04^{\prime} 54.10^{\prime \prime}$ N, 7327'19.34" E). This was achieved by interacting with the villagers over a period of 3 years. The study offers three novel contributions. First of all, it proposes an idea of adapted Water Boiling Test for a given context to measure the performance of a cookstove rather than the usual practice of carrying out standard water boiling tests [34-36]. Many researchers achieve an impressive performance enhancement in improved cookstoves after following a standard WBT in laboratory but fail to obtain the same results on the field [30-33]. The present research shows that the results of Kitchen Performance Tests, which follows field-level practice, are close to the results of the modified WBT carried out in the laboratory. The second contribution is a bottom-up approach for cookstove improvement that takes into account the existing cooking practice and brings a progressive increment in the cookstove performance. This approach increases the chances for the adoption of the improvements as compared to many improved cookstove programs (as discussed in the previous subsections) that build a new cookstove (without taking in to account the existing cooking practice) and try to disseminate it in a particular context. It was proven that the combustion and heat transfer of a cookstove can be improved by the introduction of an optimal combination of twisted tapes (with a particular width, number, and twist angle) in the hearth of the cookstove. It effectively enhances heat transfer coefficient by imparting turbulence to the air draft. At the same time, the turbulence also improves combustion by enhancing mixing of air and fuel.

\section{Method}

The present method adopts a bottom-up approach that emphasizes on understanding the local context and building on it. Such an approach is credited with having a high potential to result in socially and technologically appropriate solutions. Such solutions, in turn, have a greater probability of widespread adoption and long-term sustainability [18]. Towards this end, people's participation, not only in terms of involvement but also in terms of their control in deciding and planning, was sought in every field-level step that was adopted to develop the fuel-efficient cookstove. These steps involved goal setting, study of existing practice, field-level tests, and feedbacks. An emphasis was placed on the study of existing cooking practices after the appreciation of its importance in the present context. To ensure a high degree of social adoption and so to bear minimal variation from the existing cooking practice, it was decided to make small changes in the existing cookstoves by adopting a few guidelines from existing improved cookstove technologies.

Drawing from the abovementioned bottom-up approach, a different methodology was adopted for successful improvement of the traditional cookstove and its commercialization in Gawand wadi. The steps involved in this 
methodology are described here in short. Each of these steps is elaborated in later sections.

(1) Understanding of present context: This was accomplished by studying, documenting, and analyzing the village residents from the view point of their assets, activities, energy resources, and utilization of human work hours to carry out different livelihood activities.

(2) Goal setting: The goal of this project was decided by involving the villagers thoroughly. People's participation was ensured with the help of a set of surveys/studies. These included the problem-ranking exercise of the Participatory Rural Appraisal (PRA) activity [37], an energy-timeline survey of the domestic activities (similar to the surveys carried by Date [38] and Reddy [39]), and a health survey.

(3) Field-level investigation of existing practice: This was carried by focused group discussions with women and potters (who make the cookstoves), measurements of existing cookstove dimensions, a walk through the firewood fetching area, and experiments to find the performance of traditional cookstoves. A detailed documentation of the cooking operation was carried out by selecting six households in the village that represent the differences in family size, number of women per unit family, and type of cookstove. The details of the selection procedure are discussed in the section, 'Field-level experimentation'.

(4) Adapted water boiling tests: Accommodating the context-specific practices, two types of WBT, namely, single-pot and two-pot WBTs, were designed to measure performance indices of the cookstove.

(5) Improvements in the traditional cookstove: To ensure minimal variation from the traditional practice (as explained in points 3 and 4 of the Section, 'Learning from the improved cookstove programs'), the traditional cookstove itself was sought to be modified by either optimizing the existing design specifications and/or retrofitting a new device (such as a chimney) in the existing cookstove. The modification was first implemented and tested in the laboratory.
(6) Field-level experimentation: The proposed modification was tested in the field in the six selected families by adopting the modified water boiling tests and kitchen performance test. To mimic the existing cookstove firing practice, the women from the households themselves fired the cookstoves to carry out field-level experiments.

(7) Local manufacturing and distribution: Local artisans (blacksmiths) were involved in making any device that needed to be added to the cookstove. An arrangement was also worked out so that the blacksmith would make and sell these products along with his regular wares (axe, sickle, etc.).

Women's involvement in terms of documentation, suggestions, and feedback at every stage of the process was the crux of the project.

\section{People's participation}

People in the village have contributed in the following ways: (1) people participated in the identification of the projects based upon their need and desires, (2) women participated in the study of the existing cooking practices, (3) women from six selected households (see Table 1) have participated in conducting field-level experiments, (4) women participated in the modification of the standard water boiling test, and (5) women participated in improving the twisted-tape device to make it user friendly. These persons have consented to take part of this study and the publication of the accompanying images.

Owing to the lack of technical knowhow required to participate in the process of analytical modeling and identification of the retrofitting (twisted-tapes inserts) for the design improvement of the traditional cookstoves followed by its laboratory level design optimization, it was not possible to involve the people in these three activities.

The following section would introduce the context of the study briefly.

\section{Understanding of the present context}

The major sources of livelihood for the villagers are a single crop rain-fed agriculture (mainly paddy and ragi),

Table 1 Selected households to carry out field-level experimentation and survey cooking practices

\begin{tabular}{|c|c|c|c|c|}
\hline Households & Family size & Number of women & Number of women per unit family size & Type of cookstove \\
\hline Ambabai Kisan Gawanda & 3 & 2 & 0.67 & Three-pot stove \\
\hline Tukibai Dhavlya Gawanda & 4 & 1 & 0.25 & Two-pot stove \\
\hline Gulab Chander Bhagat & 5 & 1 & 0.2 & Three-pot stove \\
\hline Hirabai Govinda Gawanda & 7 & 4 & 0.57 & Two-pot stove \\
\hline Shevanta Dehu Bangare & 9 & 4 & 0.45 & Two-pot stove \\
\hline Bhimabai Kalu Warghade & 14 & 3 & 0.21 & Three-pot stove \\
\hline
\end{tabular}


collection and selling/consumption of forest produce such as gum, fruits, vegetables, roots, and oil seeds, and agriculture labor in neighboring irrigated area. Occasionally, they also find wage labor work in road construction and infrastructure projects in neighboring areas. The nearest market place is located at a distance of $30 \mathrm{~km}$.

\section{Assets}

The average family size is 5.63 with nearly $63 \%$ of households between 4 to 8 . Percentages of men and women in the population are nearly equal, and the adult population (above 18 years of age) accounts for $71 \%$ of the total population. The total village land is 950 ha. Most of the land is sloping and forest land. Total cattle head is 212 with 4.07 cattle head per family, which is higher than the national average of 1.73 [40]. The surrounding forest serves as a source to collect wood fuel, wood, and other forest produce. It comprises both village-owned and governmentowned forest land. The main water sources are small earthen dam (around $200 \mathrm{~m}$ from the village center, $67,000 \mathrm{~m}^{3}$ capacity) near the village residential area and three wells.

\section{Activities}

The villagers mainly depend on local ecological resources for their livelihood, and therefore, their daily activities vary seasonally. They produce most of the things for their consumption. Their daily activities can be listed as follows:

(1) Rain-fed agricultural activities: These involve Rab preparation $^{\mathrm{d}}$, ploughing, puddling, transplanting, weeding, harvesting, threshing, and storage. The Rab activity begins in March, ploughing begins in June (following the first monsoon rain), other activities follow in the order mentioned, and storage is in October.

(2) Livestock raising: Animal raising is mainly done in the monsoon. In other seasons, animals are set free.

(3) Domestic activities: These involve firewood collection, water fetching, cooking, fish/crab catching, plinth preparation, space heating ${ }^{\mathrm{e}}$, cloth washing, etc.

(4) Employment and trade: This involves forest collection, wage labor, forest cutting, carpentry, liquor making, sand collection, bamboo work, moha seeds collection, brick making, etc.

All these activities involve exchange of time and material and energy resources, and some of them involve exchange of money. The main sources of energy are firewood, animal energy, human energy, cattle dung, grass, kerosene, state-supplied grid electricity, and food.

\section{Time line and energy utilization survey}

Different activities in the village are carried out in a varied manner by each household. An activity-time duration survey showed that the contribution of men, women, and children for all activities (mentioned in the previous section) is $34.00 \%, 62.88 \%$, and $2.94 \%$, respectively. The percentage distribution of human work hours for different activities is as follows: $29.60 \%$ (agriculture), $8.40 \%$ (animal raising), 48.50\% (domestic), and 13.40\% (employment and trade). Domestic activities, which demand most of the human work hours, are mainly carried out by women. Firewood fetching activity demands $14 \%$ of the total human work hours spent over all the livelihood activities carried out in the village for 1 year. Using the average human energy demands for different livelihood activities [38], the average per capita energy expenditure in each of these activities is listed in Table 2. Firewood fetching activity requires $9.67 \%$ of total human energy expenditure per year.

\section{Goal setting}

The level of people's participation $[41,42]$ and hence the effectiveness of any technololgy development and dissemination process would increase if the technology intervention addresses a problem that is of high priority to the concerned people. Thus it is imperative to identify the priority that the villagers attach to the need to improve the traditional cookstove.

\section{Perceived priority of problems according to severity}

A problem-ranking exercise of PRA was carried out to capture the people's perceptions so that the problems faced by the villagers could be ranked according to their severity. This was achieved by first listing out

\begin{tabular}{|c|c|c|c|}
\hline Number & Activities & $\begin{array}{l}\text { Annual per } \\
\text { capita energy } \\
\text { expenditure } \\
\text { (Gcal/year) }\end{array}$ & $\begin{array}{l}\text { Percentage of } \\
\text { energy } \\
\text { expenditure }\end{array}$ \\
\hline 1 & Animal rearing & 15.9 & 6.43 \\
\hline 2 & Agriculture & 68.0 & 26.50 \\
\hline 3 & Water fetching & 44.1 & 17.80 \\
\hline 4 & $\begin{array}{l}\text { Firewood } \\
\text { fetching }\end{array}$ & 42.9 & 9.67 \\
\hline 5 & Cooking & 14.6 & 8.24 \\
\hline 6 & $\begin{array}{l}\text { Cloth washing } \\
\text { and plinth } \\
\text { preparation }\end{array}$ & 9.9 & 4.03 \\
\hline 7 & Fishing & 3.1 & 1.25 \\
\hline 8 & Other activities & 64.5 & 26.04 \\
\hline
\end{tabular}


the problems faced by the villagers followed by individual perceptions about their hierarchy. A total of 37 people including, youth and adult men and women were interviewed. The final hierarchy was found by assigning a weight to each problem equal to the reciprocal of its rank assigned by an individual followed by a weighted average. This study revealed that the firewood fetching activity ranked first among the problems faced by the people. The hierarchy of the problems is shown in Table 3. Presently, both firewood and water fetching activities are carried out by women by carrying loads (around 20 to $32 \mathrm{~kg}$ ) on their head. Both these activities involve walking on a sloping terrain. These activities have considerable health-related impacts.

Further, 40 women across various age groups were surveyed to identify the health hazards associated with these two laborious activities. The women could be distributed into the following three approximate age groups: women below 30 years (22), between 30 and 50 years (12), and above 50 years (6). The survey revealed that most the women face problems of backache, neckache, calf muscle ache, and fatigue.

These observations combined with the results of the energy and timeline survey and those from the problemranking exercise of PRA were shared with the people in a village-level meeting (December 2009). The villagers came to a consensus that the firewood fetching and water fetching activities were the ones involving the most drudgery and should be tackled first.

The present study focuses on the improvement of the efficiency of the traditional cookstove in order to address the most pressing problem of drudgery associated with the firewood fetching activity without undermining its

Table 3 Overall problem ranking

\begin{tabular}{llllll}
\hline Problems faced & $\begin{array}{l}\text { Young } \\
\text { men }\end{array}$ & $\begin{array}{l}\text { Adult } \\
\text { men }\end{array}$ & $\begin{array}{l}\text { Adult } \\
\text { women }\end{array}$ & $\begin{array}{l}\text { Young } \\
\text { women }\end{array}$ & Overall \\
\hline $\begin{array}{l}\text { Drudgery in firewood } \\
\text { fetching }\end{array}$ & 2 & 3 & 1 & 1 & 1 \\
$\begin{array}{l}\text { Unemployment } \\
\begin{array}{l}\text { Drudgery in water } \\
\text { fetching }\end{array}\end{array}$ & 1 & 2 & 3 & 7 & 2 \\
$\begin{array}{l}\text { Lack of health } \\
\text { care in village }\end{array}$ & 9 & 5 & 2 & 2 & 3 \\
$\begin{array}{l}\text { Low level of } \\
\text { education }\end{array}$ & 4 & 6 & 8 & 9 & 5 \\
$\begin{array}{l}\text { Liquor addiction } \\
\text { Lack of toilets }\end{array}$ & 6 & 4 & 7 & 6 & 6 \\
$\begin{array}{l}\text { Lack of transportation } \\
\text { facilities }\end{array}$ & 5 & 8 & 6 & 5 & 8 \\
$\begin{array}{l}\text { Sporadic electricity } \\
\text { supply }\end{array}$ & 8 & 10 & 9 & 8 & 9 \\
\begin{tabular}{l} 
Snakes bites \\
\hline
\end{tabular} & 7 & 9 & 10 & 10 & 10 \\
\hline
\end{tabular}

effect on indoor air pollution. The problem associated with drudgery in water fetching was tackled differently.

\section{Cooking practice}

\section{Design of traditional cookstove}

There are two types of traditional cookstoves, namely, two-pot and three-pot cookstoves, as shown in Figure 1. There is a common fire input port to feed firewood for both of these stoves. There are 26 two-pot stoves and 28 three-pot stoves in the village. Three-pot stoves are usually found in larger families. Women feel that twopot stoves are more efficient than three-pot stoves. In the case of three-pot stoves, the third hole is used for a short duration of cooking operation during the day. At all other times, flames come out of this third hole, and heat is lost. Yet, as there is an additional hearth, cooking is faster on the three-pot stoves. The average dimensions of the cookstoves in the village are listed in Table 9 in Appendix 1.

\section{Cookstove construction}

Many households in Gawand wadi make their own cookstove. The remaining households get it manufactured by a few people in the village by offering them a meal. Very few households (presently two) buy cookstoves from potters in nearby villages. The manufacturing process of the cookstoves is elaborated in Appendix 2.

\section{Firewood}

The socio-technical aspects of firewood (such as firewood fetching and characterization of firewood) are discussed below:

(1) Firewood fetching activity: Women fetch firewood from the local forest. Every year, this activity starts after paddy harvesting (November) and continues until the end of the next summer. Figure 2 shows an approximate area from which women fetch firewood in Gawand wadi. The dotted line indicates a path travelled by women during winter season to fetch firewood. It is typically 4 to $5 \mathrm{~km}$. The thick line indicates the firewood fetching path during summer season. It is typically 6 to $7 \mathrm{~km}$. The time required to fetch a firewood bundle varies from 3 to $4 \mathrm{~h}$ in winter to 5 to $6 \mathrm{~h}$ in summer. Initially, tree branches, fallen during monsoon storms, are collected. The area traced per day to collect these branches increases gradually, thereby increasing the daily time required to fetch a firewood bundle. Eventually, when it is very difficult to get fallen wood branches, small-diameter $(<5 \mathrm{~cm})$ tree branches are cut. This branch cutting operation demands more human energy than just collection. The typical weight of a firewood bundle carried by women varies from 20 to $32 \mathrm{~kg}$ depending 


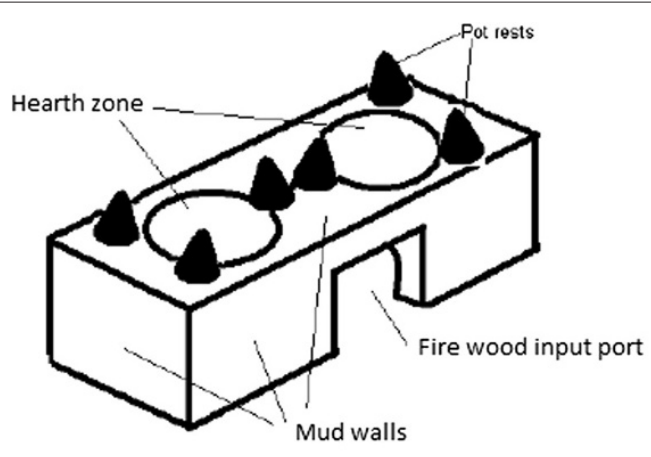

(a)

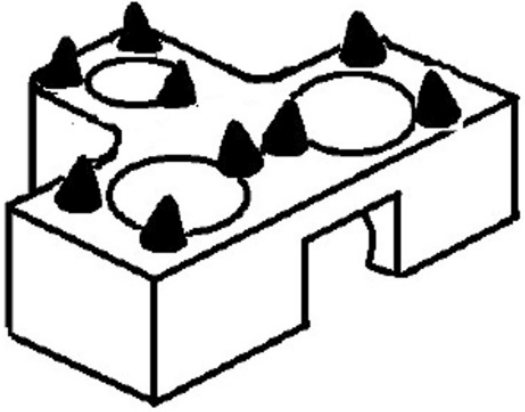

(b)

Figure 1 Traditional cookstoves. (a) Two-pot stove and (b) three-pot stove. These stoves are built from clay by people or local potters

upon the load carrying capacity of the woman and the firewood requirement of the household. Figure 3 shows the undulated elevation profile of a path travelled by women to carry firewood during winter. Firewood fetching activity can be divided in to five subtasks. These are to reach the forest area, to collect firewood, to tie the bundle of wood with a thin stem of a creeper or bark of a few tree species, to cut tree branches if required, and to carry firewood home. A typical time breakup required to carry these tasks is shown in Table 4.

(2) Wood species which are used as firewood are ain (Terminalia elliptica), dhamada (Angeissus latifolia), chera (Erinocarpus nimmonii), karvanda (Carissa carandas), bondari (Lagerstroemia parviflora), nana (Lagerstroemia microcarpa), akashi (Salix babylonica), kuda (Holarrhena pubescens), sag (Tectona grandis), etc. Out of these, dhamada, ain, and nana give a good flame. An approximate usage pattern of different firewood species perceived by villagers is shown in Table 5.

(3) Properties of firewood: Firewood species which are mainly used for cooking were characterized by finding seasonal moisture content, calorific value, and proximate analysis as listed in Table 5. The calorific value was measured using a bomb calorimeter. The proximate analysis was carried using an electric furnace. A dry wood sample (around $1 \mathrm{~g}$ )

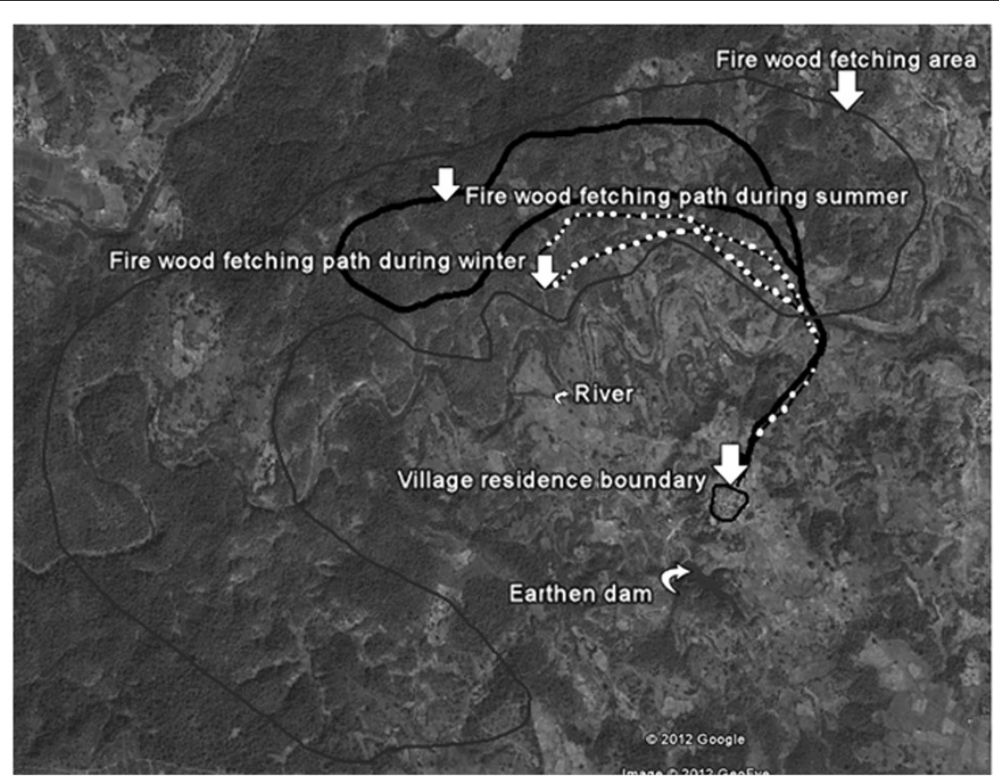

Figure 2 Firewood collection area in Gawand wadi [43]. An approximate area from which women fetch firewood in Gawand wadi. It spans around $10 \mathrm{~km}^{2}$. The dotted line indicates a path travelled by women during the winter season to fetch firewood. It is typically 4 to $5 \mathrm{~km}$. The thick line indicates the firewood fetching path during the summer season. It is typically 6 to $7 \mathrm{~km}$. 


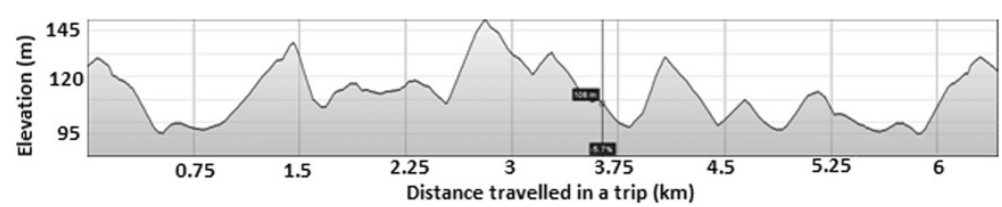

Figure 3 Firewood fetching path during the winter season in Gawand wadi [43]. Elevation of a firewood fetching path traced during winter as shown by dotted line in Figure 5 . It shows that the path is quite undulated. The difference between the highest and the lowest location is around $50 \mathrm{~m}$.

was heated in an electric furnace at $550^{\circ} \mathrm{C}$ for $7 \mathrm{~min}$ and then at $750^{\circ} \mathrm{C}$ for an additional $2 \mathrm{~min}$ to find the percentage of volatile matter in the wood species by measuring the percentage reduction in the weight. It was further heated at $750^{\circ} \mathrm{C}$ for $4 \mathrm{~h}$ to find the percentage of carbon in the sample by calculating the reduction in weight. Tabulated values of calorific values and proximate analysis are averages of three such experiments with less than $5 \%$ of variation. Moisture content was measured by the following method: A fixed quantity $(100 \pm 20 \mathrm{~g})$ of wood was dried in an electric oven at $105^{\circ} \mathrm{C}$ for $24 \mathrm{~h}$. The fraction of moisture was calculated by subtracting the fraction of dried wood mass. The moisture content varies with season. During rainy season, the moisture content for 3-cm diameter ain wood is around $18 \%$ to $20 \%$. It varies from $8 \%$ to $14 \%$ during summer and winter seasons.

(4) Typical firewood dimensions: The firewood diameter lies in the range of 1 to $5 \mathrm{~cm}$. To obtain a good flame, firewood of 1.5 to $4 \mathrm{~cm}$ diameter is used. For the initial ignition of fire, wood sticks below $1.5-\mathrm{cm}$ diameter are used. Firewood of diameter larger than $5 \mathrm{~cm}$ is usually chopped. The length of firewood lies in the range of 50 to $70 \mathrm{~cm}$.

(5) Wood requirement per year: This varies with family size. For an average family size of six, the wood requirement per year is around $2,700 \mathrm{~kg}$.

\begin{tabular}{lll}
$\begin{array}{l}\text { Table } 4 \text { Approximate time breakup for different tasks } \\
\text { performed in firewood fetching activity }\end{array}$ & $\begin{array}{l}\text { Average time } \\
\text { required in } \\
\text { winter (h) }\end{array}$ & $\begin{array}{l}\text { Average time } \\
\text { required in } \\
\text { summer (h) }\end{array}$ \\
\hline Tasks & 0.5 & 0.7 \\
\hline To reach forest area & 2 & 4 \\
To collect wood sticks & 0 & $\begin{array}{l}3 \text { (wood either } \\
\text { is collected } \\
\text { or cut) }\end{array}$ \\
To cut tree branches & 0.25 \\
To tie bundle with a climber & 0.25 & 1 \\
To carry firewood bundle home & 0.75 & 5 to 6 \\
Total & 3.5 & a
\end{tabular}

\section{Cookstove-firing practice}

This was studied by observation of actual cooking, a questionnaire survey, measurement of coal formation and temperature at different parts of the hearth zone, and direct experience of cookstove firing. The following are the observations:

(1) Kerosene is used for the initial ignition of firewood. Comparatively dried and smaller diameter wood is preferred for the initial burning. It usually takes 2 to 3 min to achieve a steady-state flame.

(2) Usually, two or three larger diameter wooden sticks $(4$ to $6 \mathrm{~cm}$ ) and a few smaller diameter sticks (2 to $4 \mathrm{~cm})$ are fired simultaneously to attain the required heating rate.

(3) In general, 50 to $70 \mathrm{~cm}$ long wood sticks are preferred so that the fire can be adjusted easily by slight movement of these sticks. Firewood is arranged in such a manner that sufficient primary air can pass through the fuel feed port.

(4) If necessary, the women blow air by mouth to maintain a good flame size.

(5) Red hot charcoal helps sustain the flame. It is necessary to remove the excess charcoal if it is accumulated in the hearth zone to make space for the firewood.

(6) The woman who is cooking sits on one side of the cookstove to avoid exposure to radiated heat from the wood insertion hole.

\section{Durability}

On an average, a cookstove lasts for 2 to 3 years before its disintegration. Usually, its fuel feeding hole disintegrates first. It wears due to frequent friction between firewood sticks and its edges. Pot rests also disintegrate as these wear due to regular loading and unloading of pots.

\section{Food preparations}

There are three types of food preparations, namely, baking (bhakari or roasted bread), boiling (heating water, rice, curry, and tea), and frying (vegetables dishes and fish/crab curry). Table 6 lists the average food preparation time, the pot size, and the duration of operation for a two-pot cookstove for a family of six. It shows that nearly $32 \%$ of the operations are carried in the single-pot mode, and $68 \%$ in 
Table 5 Wood species wise usage percentage and calorific value

\begin{tabular}{|c|c|c|c|c|}
\hline Wood species & $\begin{array}{l}\text { Perceived usage } \\
\text { in percentage }\end{array}$ & Calorific value (MJ/Kg) & $\begin{array}{l}\text { Percentage } \\
\text { of volatiles }\end{array}$ & $\begin{array}{l}\text { Percentage } \\
\text { of carbon }\end{array}$ \\
\hline Ain (Terminalia elliptica) & 50 & 16.8 & 76.5 & 22.3 \\
\hline Dhamda (Angeissus latifolia) & 20 & 17.9 & 72 & 26.5 \\
\hline Chera (Erinocarpus nimmonii) & 10 & 17.9 & - & - \\
\hline Kuda (Holarrhena pubescens) & 10 & 17.3 & - & - \\
\hline $\begin{array}{l}\text { Sag (Tectona grandis), karvanda (Carissa carandas), } \\
\text { bondari (Lagerstroemia parviflora), akashi (Salix } \\
\text { babylonica), and others }\end{array}$ & 10 & $\begin{array}{l}\text { sag (16.6), karvanda (16.6), bon- } \\
\text { dari (17.1), akashi (17.3) }\end{array}$ & - & - \\
\hline
\end{tabular}

the two-pot mode for a two-pot cookstove. Correspondingly, for three-pot stoves, the percentage of operation in the two-pot mode and the three-pot mode is 54 and 14, respectively.

\section{Input power of cookstove}

The input power is the energy input to the cookstove per unit time. It varies with recipes, cookstove dimensions, family size, and cookstove firing practice. The capacity of a cookstove increases with the size of cookstove or the volume of hearth zone. Usually, tea brewing and rice making requires lesser amount of input power. Other practices such as water boiling require higher amount of power input to the cookstove. If the number of women in the family is low (one or two), they tend to reduce the time required for cooking by firing the cookstove at higher input power in order to spare more time for other activities.

Power input to the cookstove is evaluated by two different ways as follows:

(1) The ratio of hearth zone volume to input power of cookstove follows a rough rule of thumb of $0.6 \mathrm{l} / \mathrm{kW}$ [44]. Using an average hearth zone volume of 9.41 (for two-pot cookstove), the power input to the cookstove is $15.6 \mathrm{~kW}$ if it is used in the two-pot mode. For single-pot mode operation, the average hearth zone volume is $6.5 \mathrm{l}$, and thus, the estimated power input is $10.8 \mathrm{~kW}$.

(2) Water boiling tests carried out on the selected cookstoves yielded an average input power of around $14.6 \mathrm{~kW}$ for two-pot mode of operation and $8.46 \mathrm{~kW}$ for single-pot mode of operation. This value is closer to the input power $(14 \mathrm{~kW})$ measured by Geller [45] in the village of Ungra near Bangalore.

\section{Experimental procedure}

Table 6 shows that around $40 \%$ of the daily firewood is utilized in water boiling for bathing. It is the operation consuming the most amount of firewood. Other activities including tea brewing and rice and curry making are close to the water boiling operation, and these activities cumulatively comprise more than $85 \%$ of the cooking operations. Therefore, a WBT and a kitchen performance test (KPT) $[36,46,47]$ that involves a real time evaluation of the daily cooking practice were used to the water boiling test, a fixed amount of water is boiled on

Table 6 Average daily cookstove practice of an average family of size six

\begin{tabular}{|c|c|c|c|c|c|c|c|c|c|}
\hline $\begin{array}{l}\text { Cookstove } \\
\text { preparations }\end{array}$ & $\begin{array}{l}\text { Per capita } \\
\text { per meal } \\
\text { requirement }\end{array}$ & $\begin{array}{l}\text { Duration } \\
\text { (min) }\end{array}$ & $\begin{array}{l}\text { Number of } \\
\text { daily } \\
\text { preparations }\end{array}$ & $\begin{array}{l}\text { Total } \\
\text { preparation } \\
\text { time } \\
\text { (min) }\end{array}$ & $\begin{array}{l}\text { Pot } \\
\text { diameter } \\
(\mathrm{cm})\end{array}$ & $\begin{array}{l}\text { Pot } \\
\text { height } \\
\text { (cm) }\end{array}$ & $\begin{array}{l}\text { Single-pot } \\
\text { mode (min) }\end{array}$ & $\begin{array}{l}\text { Two-pot } \\
\text { mode }(\min )\end{array}$ & $\begin{array}{l}\text { Wood } \\
\text { consumption } \\
\text { (kg) }\end{array}$ \\
\hline $\begin{array}{l}\text { Water } \\
\text { boiling } \\
\text { for bathing }\end{array}$ & 4.21 & $21 \pm 2$ & 5 & 105 & $27.5 \pm 1.5$ & $16 \pm 2$ & 42 & 63 & 2.9 \\
\hline Tea & $76.3 \mathrm{~g}$ & $10 \pm 1$ & 3 & 30 & $14 \pm 1$ & $7 \pm 1$ & 10 & 20 & 0.75 \\
\hline Rice & $141 \mathrm{~g}$ & $24 \pm 4$ & 2 & 50 & $19 \pm 2$ & $12 \pm 2$ & & 48 & 1.3 \\
\hline Bhakri & $162 \mathrm{~g}$ & $24 \pm 10$ & $\begin{array}{l}\text { Once in } \\
3 \text { days }\end{array}$ & 8 & $26 \pm 2$ & 5 & & 8 & 0.2 \\
\hline $\mathrm{Da}^{\mathrm{a}}$ & $24 \mathrm{~g}$ & $35 \pm 5$ & 2 & 80 & $17 \pm 2$ & $9 \pm 2$ & & 70 & 1.7 \\
\hline Bhaji & & $12 \pm 3$ & 2 & 24 & $26 \pm 2$ & 5 & & 24 & 0.62 \\
\hline Total & & & & & & & 55 & 115 & 7.4 \\
\hline
\end{tabular}

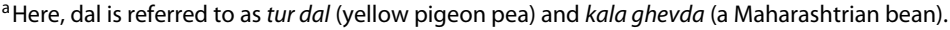


a cookstove, and the efficiency is calculated by dividing the total heat transferred to water by the total heat input.

The components of the cookstove system are operator, firewood, cookstove design, pot, and type and amount of food to be cooked. Each component plays a role to influence the performance of a cookstove. Therefore, the water boiling test was modified to accommodate existing cooking practice defined by these components. The modifications are listed below:

1. To mimic existing cookstove firing practice, it was decided to let women fire the cookstove while carrying WBTs on field (see Figure 4).

2. Time duration of WBT: Most of the cooking preparations in the village last for a little less than half an hour as documented in Figure 5. Therefore, it was decided to carry WBT for half an hour.

3. Fuel size: For field-level testing, wood of 2 to $5 \mathrm{~cm}$ diameter and 50 to $70 \mathrm{~cm}$ length was used, the wood species being mainly ain and dhamda. For laboratory level testing, wood of $2.5 \pm 0.5 \mathrm{~cm}$ diameter and $25 \pm$ $2 \mathrm{~cm}$ length was used.

4. Power input: $8.5 \mathrm{~kW}(1.81 \mathrm{~kg}$ firewood $/ \mathrm{h})$ in single-pot mode and $14 \mathrm{~kW}(3.2 \mathrm{~kg}$ firewood $/ \mathrm{h})$ in two-pot mode of operation.

5. Weight of water: $5.5 \mathrm{l}$ (average water usage for the cooking preparations).
6. Pot size: 26 to $31 \mathrm{~cm}$ (range of pot sizes used in the village to boil the bathing water).

7. Timing to carry out tests: 11 am to $5 \mathrm{pm}$.

8. Starting condition: Hot start, owing to the hot start condition for most of the cooking preparations. This step was added after obtaining feedback from the women.

\section{Kitchen performance test}

KPT measures the average rate of firewood consumption by a stove in a normal household environment [36]. A wood pile (mainly including the wood species ain and dhamda) of $100 \pm 15 \mathrm{~kg}$ was stacked in a household, and the rate of consumption of firewood per household was found by dividing the total consumed weight of wood by the number of days of its consumption.

\section{Proposed improvement}

Cookstove operation comprises three phenomena that occur simultaneously, namely, (a) burning of fuel, (b) mass transfer of air, volatile gases, and gaseous products of combustion, and (c) heat transfer to pot and other parts of the stove $[48,49]$. The overall thermal efficiency $\left(\eta_{t}\right)$ of the cookstove depends upon three intermediate efficiencies, namely, combustion efficiency of fuel $\left(\eta_{c}\right)$, heat transfer efficiency to pot $\left(\eta_{h}\right)$, and efficiency at which pot transfers energy to food $\left(\eta_{p}\right)$. The efficiency value $\eta_{p}$ depends upon pot size which is usually determined by

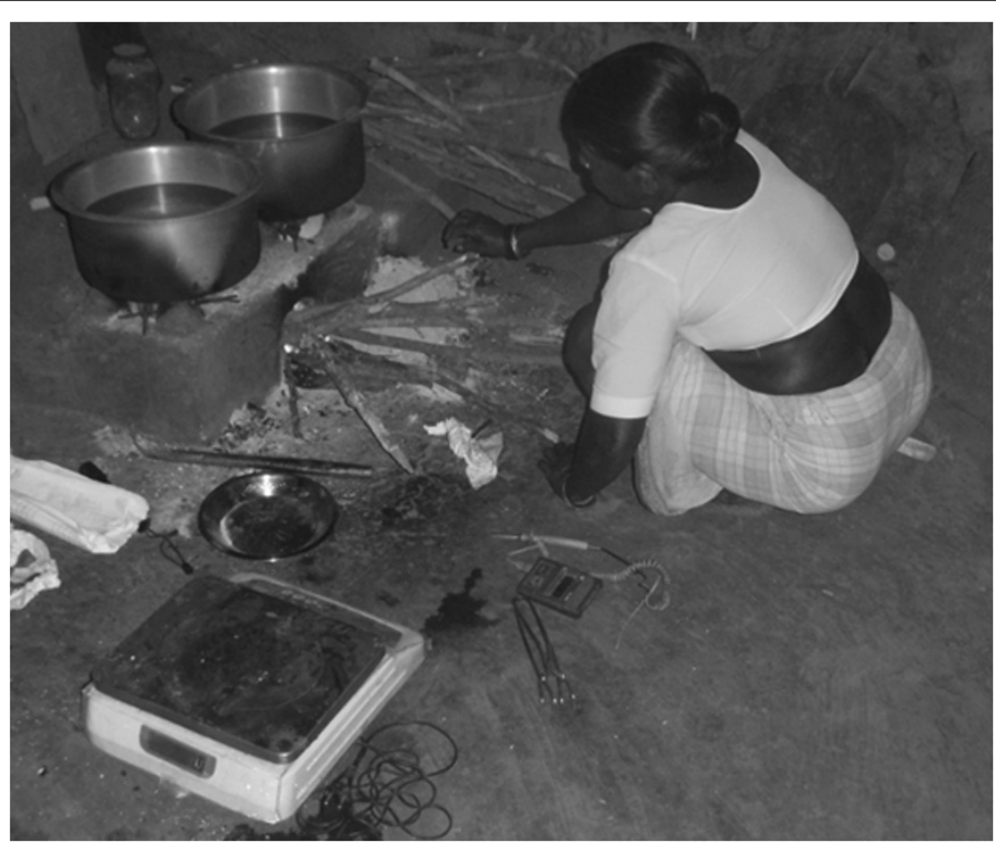

Figure $4 \mathrm{~A}$ woman firing cookstove in a two-pot water boiling test. Water boiling tests in the village were carried out with women, where a woman who cooks food fired her cookstove to find out its performance. 


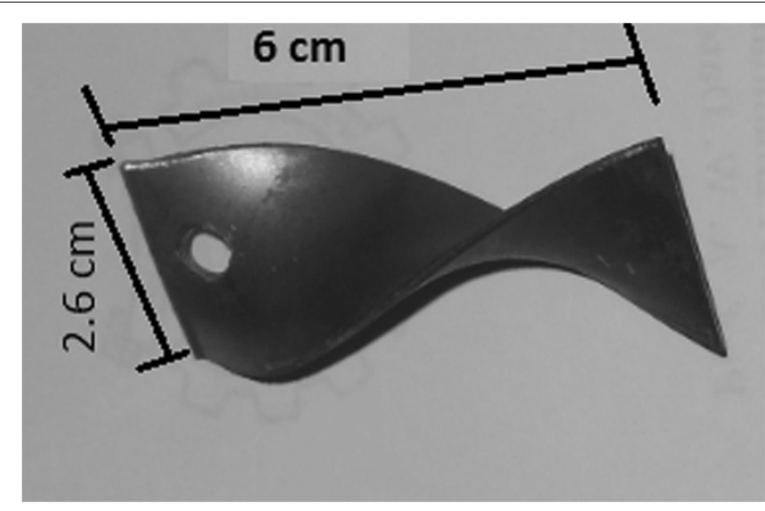

Figure 5 A twisted mild steel plate.

food type. The thermal efficiency can be improved by either optimizing the design specifications (see Figure 12 in Appendix 1) or retrofitting a certain device (such as a chimney) in the existing cookstove or both to improve heat transfer efficiency and/or combustion efficiency.

To study the cookstove operation for its design improvement, a steady state analytical model was developed by splitting the hearth into three zones to study char combustion, volatile combustion, and heat transfer to the pot bottom separately. A study of the variation of design specifications on the thermal performance revealed that the traditional cookstove specifications are close to their optimal values. A Sankey diagram (see Figure 15 in Appendix 3) of the cookstove operation revealed that the major thrust areas to improve the thermal performance are the heat transfer to the pot and combustion of volatiles ${ }^{\mathrm{f}}$.

It has been documented that the incorporation of twisted tapes (TTs, see Figure 5) in the hearth generate swirl motion of the gases which improves the jet impingement heat transfer [50,51] at the pot bottom. It also improves combustion of volatiles by increasing air-fuel mixing and the residence time of the reactant gases [52,53]. Bhandari et al. [47] found that the inclusion of twisted tapes improved the efficiency of an experimental cookstove. It was decided that the effect of the inclusion of twisted tapes to improve the thermal performance of the traditional cookstove be investigated.

\section{Results and discussion}

Effect of variation of number of twisted tapes on thermal performance of cookstove

\section{Manufacturing in the laboratory}

The twisted tapes were manufactured by twisting a mild steel plate heated to $300^{\circ} \mathrm{C}$. The strip dimensions used for laboratory tests were the following: for the width, $1.25,2.54$, and $3.38 \mathrm{~cm}$; length, $6 \mathrm{~cm}$; and thickness, 1.5 $\mathrm{mm}$. The tapes were twisted by holding them in a fixture together with a lathe machine. To ensure smooth twist, the tapes were heated with a torch blower, and the twisting procedure was implemented in four to five steps.

\section{Retrofitting of twisted tapes}

TTs were retrofitted in a cookstove by just inserting them in two or more steel rods and keeping the rods on the holes of the hearth to let the TTs hang in the hearth as shown in Figure 6. Thus, the intervention does not change the existing cookstove design. The new cookstove is similar to the existing one and would address the concerns raised in point numbers 3 and 4 of the Section "Learning from the improved cookstove programs".

\section{Outcomes of laboratory tests}

A two-pot cookstove, made by a local potter, was used for the laboratory-level experimentation. Its specifications are listed in Table 10 in Appendix 1. The two-pot water

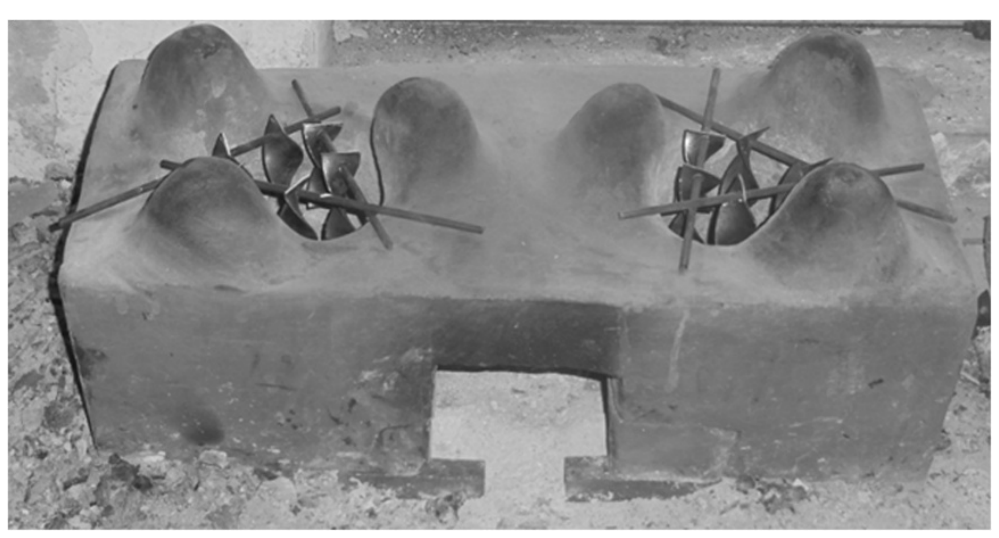

Figure 6 Twisted tapes hanging in the hearth holes. This shows the way to hang the twisted tapes in the hearth holes by using steel rods. They are placed in a way that they cover the cross-section of the hearth evenly. 
boiling tests were carried out by varying the number of TTs in each hearth (experimental set-up is shown in Figure 7). The water boiling tests were carried out in the following order:

(1) Varying the number and width of the twisted tapes in each hearth for the same twist angle $\left(180^{\circ}\right)$.

(2) Varying the twist angle $\left(0^{\circ}, 60^{\circ}, 120^{\circ}, 180^{\circ}\right.$, and $\left.240^{\circ}\right)$ for optimum width and number of twisted tapes ( $2.54 \mathrm{~cm}$ and seven, respectively).

(3) Carrying a few additional WBTs with optimum width and twist angle $\left(2.54 \mathrm{~cm}\right.$ and $180^{\circ}$, respectively) to study the effect on exhaust gas composition and soot. This helps in understanding the contributions due to the twisted tape assembly.

It was observed that the thermal efficiency of the cookstove was optimum (improvement by $24.5 \%$ ) for inclusion of seven number of twisted tapes having a width of $2.54 \mathrm{~cm}$ and a twist of $180^{\circ}$. A few additional WBTs with optimum width and twist angle showed that the proposed retrofitting improves combustion of the volatile gases (see Table 7). It was also observed that the amount of soot accumulated over the outer surface of the pot decreases by around 38\% (see Table 7) by inclusion of these TT inserts. A detailed analysis of the laboratory level WBTs is not discussed in the present report and will be presented elsewhere. It was decided that field-level tests by retrofitting seven TTs of $2.54 \mathrm{~cm}$ width and $180^{\circ}$ twist angle in each hearth be carried out.

\section{Field level experimentation}

Field-level experiments were carried out at the six selected households in the following order: single-pot water boiling test, two-pot water boiling test, and kitchen performance test. The method of selecting the households is explained below.

\section{Selection of the households}

It was first noted that the cookstove size and firewood requirement increase with family size (see Figures 13 and 14 in Appendix 1). If the number of women per unit family size is higher, firewood fetching and cooking activities get distributed among women, and it reflects in the human work hour involvement and drudgery associated with it. If the number of women per unit family size is lower, women try to fire the cookstove with a higher input power in order to accomplish the cooking task earlier. Figure 8 shows all the existing combinations of the family size and number of women per unit family size in the village. The data points are then divided in four quadrants as shown. Depending on the willingness of the family members to participate in field-level experimentation and the type of cookstove (two-pot or three-pot), four different households from each quadrant were selected along with two households from extreme ends (encircled in Figure 9 and listed in Table 1). As there are nearly equal number of two-pot and three-pot stoves in the village, it is ensured that three out of the six selected households have three-pot stoves. The dimensions of the cookstoves are listed in Table 11 in Appendix 1.

\section{Single-pot water boiling test}

By introducing seven TTs, the thermal efficiency of the cookstove increases by an average of $20.61 \pm 1.98 \%$, and the specific fuel consumption of cookstove is decreased by $14.5 \pm 1.32 \%$ (at the statistical significance level of 0.05 for both the outcomes).

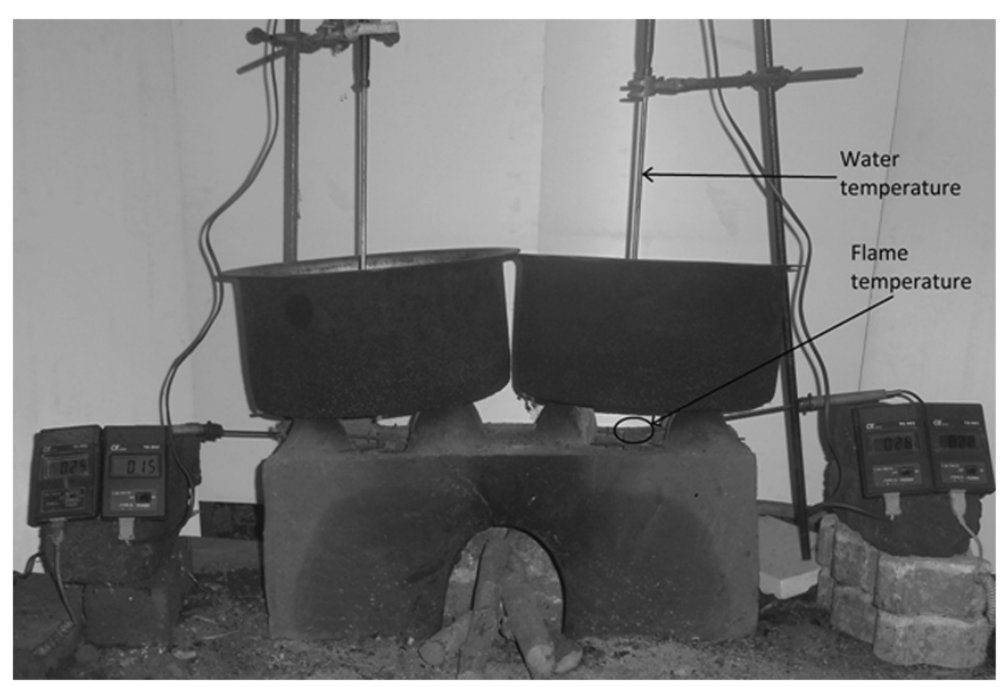

Figure 7 Experimental set-up to carry two-pot WBT in the laboratory. This shows the experimental set-up that was used to carry out the laboratory WBTs. Four thermocouples were used to measure the temperature of water and flame for both the pots and hearths. 
Table 7 Soot accumulation and percentage composition of the gases at the center of the stove top

\begin{tabular}{llll}
\hline & $\mathbf{O}_{\mathbf{2}}(\mathbf{\%})$ & $\frac{\mathbf{C O}}{\mathbf{C O}_{\mathbf{2}}}$ & Soot $(\mathbf{g})$ \\
\hline Normal cookstove & 10.5 & 0.087 & 2.84 \\
Seven TTs & 5.5 & 0.082 & 1.75 \\
Eleven TTs & 7.8 & 0.080 & 2.20 \\
\hline
\end{tabular}

The listed values are averages of three WBTs.

\section{Two-pot water boiling test}

The thermal efficiency of the cookstove increases by an average of $22.82 \pm 2.48 \%$, and specific fuel consumption of the cookstove decreases by $15 \pm 1.29 \%$ (at the statistical significance level of 0.05 for both the outcomes) by retrofitting of TTs in existing cookstove (see Figure 10 and 11).

\section{Kitchen performance test}

The results of the KPT are shown in Table 8. Corrections in wood consumption of the families due to presence of guests were incorporated by considering an average firewood usage for food preparations as listed in Table 6. The results of KPT show (see Table 8 ) a reduction of $21.3 \pm 1.89 \%$ (at the statistical significance level of 0.05 ) in the average daily wood consumption.

The results of the kitchen performance test show that the percentage increase in the performance of cookstove is lower than that indicated by WBTs. Once the cooking preparations in the morning, noon, or evening are completed, the women leave accumulated coal inside the hearth itself. It slowly burns and decreases in weight until the next operation starts. Secondly, if the coal accumulation prohibits insertion of firewood in the hearth zone, the women take the coal out of the cookstove and throw it away. Thus, all the coal that remains at the end of cooking operations is not utilized. Hence, the percentage decrease in wood consumption is lower (by around $3 \%)$ than the percentage increase in the thermal efficiency. Yet, as some amount of the remaining coal is still utilized for further food preparation, the percentage decrease in average wood consumption is higher in KPT than the percentage decrease in specific fuel consumption (by around 4\%) in WBT.

As KPT gives actual improvements in the cookstove performance by enabling real-time monitoring of the cooking performance, it is a more relevant test. Furthermore, as water boiling is a major cookstove operation (see Table 6), the results shown by the water boiling tests are closer to those shown by the kitchen performance test.

\section{Women's feedback}

The women in the six selected households gave the following feedbacks regarding the retrofitting of TTs in their cookstoves:

(1) Improvement in the cookstove has reduced wood consumption by roughly $25 \%$ (as per their estimate).

(2) Soot accumulation over the outer surface of pots has reduced.

(3) Time required to prepare different food items has reduced.

(4) Women found that sometimes the steel rod holding the TT would fall inside the hearth zone due to lateral force exerted by firewood on TTs. If this problem is removed, it would be wonderful.

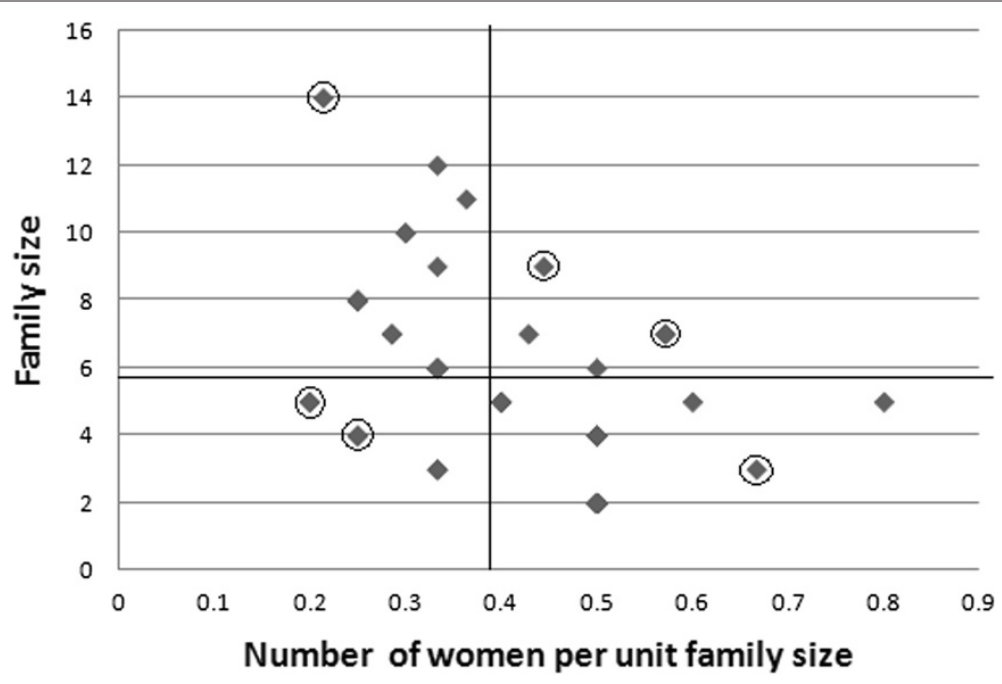

Figure 8 Family size versus number of women per unit family wise in Gawand wadi. The graph shows all possible combinations of family size and women per unit family size. The sample space is divided in four quadrants for even selection of the households across such variations. Encircled families were selected. 


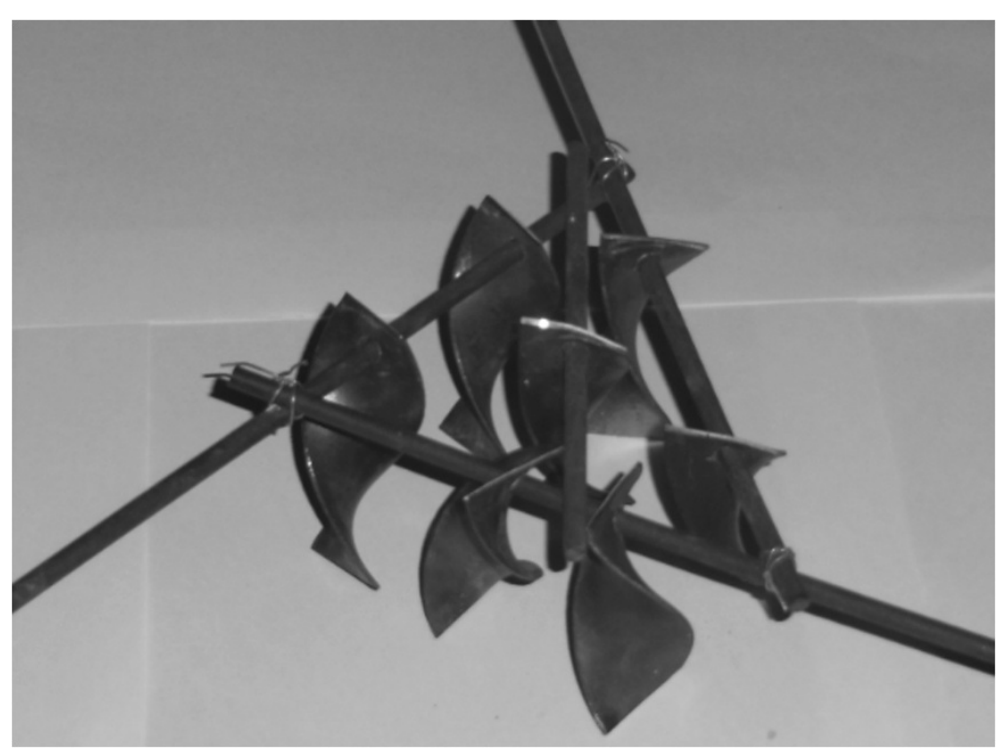

Figure 9 TT pack. This shows a twisted tape pack that can be retrofitted in the traditional cookstove.

A new retrofitting was devised as a result, in which the seven TTs are inserted in a welded triangular rod structure as shown in Figure 9. It does not fall in the hearth and is very easy to place and remove from the stove. Women liked this new design.

\section{Commercialization through local artisans}

Commercialization involves manufacturing and distribution of the technology. Bottom-up approach emphasizes building on the local human skills and the local socioeconomic structure. The improvement is found to be not very sensitive to the slight changes in the width and twist angle of the twisted tape. Thus, local manufacturing and dissemination of the TT packs was found to be an impressive alternative. The success of the dissemination of an improved cookstove program depends upon multiple factors [54] that vary with context. Although many dissemination programs emphasized on training local people

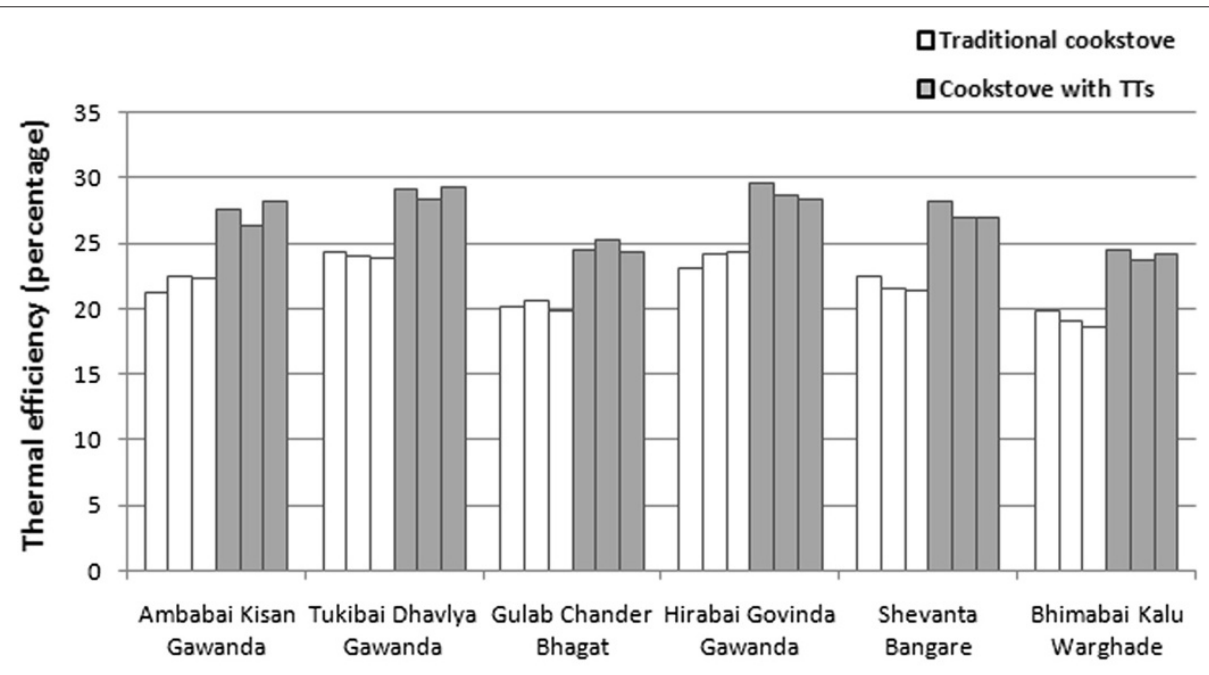

\section{Households named by a member}

Figure 10 Effect of retrofitting of TTs on thermal efficiency of traditional cookstoves in Gawand wadi. This shows the results of the two-pot water boiling tests that were carried out in six selected households. Traditional cookstove and cookstove with inclusion of TTs were tested by carrying out three tests for each kind of cookstove. It can be observed that the thermal efficiency of the cookstove increases by the inclusion of $T$ s for every household. 


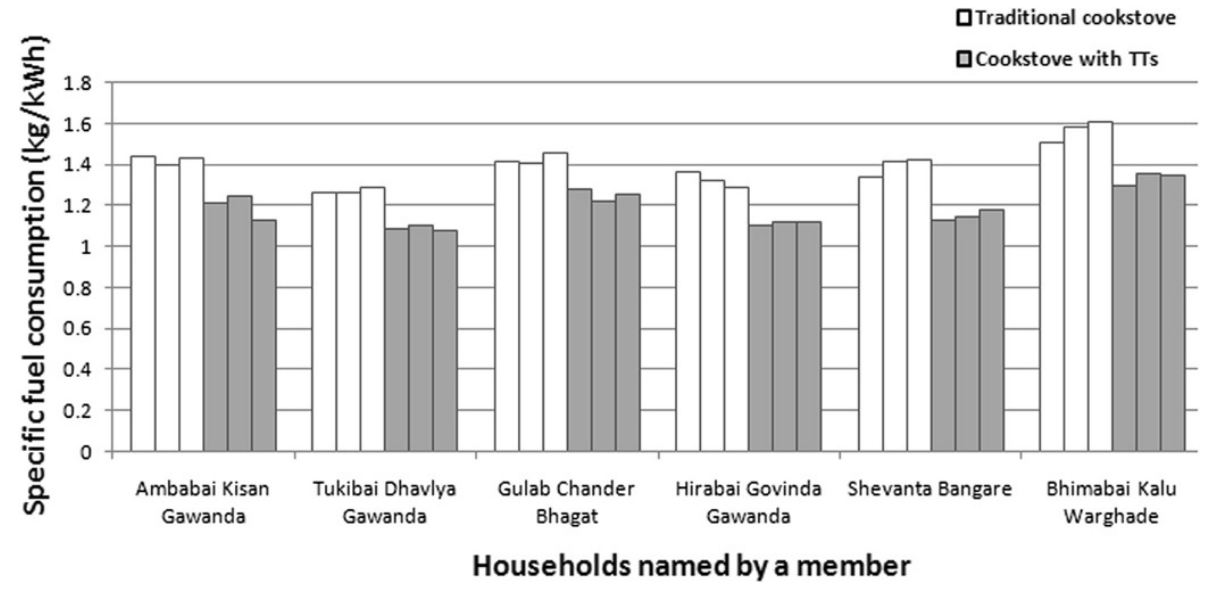

Figure 11 Effect of retrofitting of TTs on specific fuel consumption of traditional cookstoves in Gawand wadi. Figure shows results of the two-pot water boiling tests that were carried out in six selected households. Traditional cookstove and cookstove with the inclusion of Tाs were tested by carrying out three tests for each kind of cookstove. It can be observed that the specific fuel consumption of the traditional cookstove decreases by the inclusion of TTs for every household.

for manufacturing and marketing of improved cookstoves $[20,55]$, it was found that at many places, these enterprises get poor benefits, so they have little motivation to start and sustain the business [9]. Therefore, if a local artisan is trained to accommodate the manufacturing and selling of improved cookstoves in his/her existing sociocommercial business, there is a greater probability for its sustenance. In the present context, manufacture and dissemination of the TT packs through the existing business structure of the local blacksmiths is sought. Traditionally, they make and repair sickles, axes, ploughs, and

Table 8 Results of kitchen performance test at two households

\begin{tabular}{lcc}
\hline Household & Operation conditions & $\begin{array}{c}\text { Average } \\
\text { daily wood } \\
\text { requirement } \\
\text { (kg/day) }\end{array}$ \\
\hline Ambabai Kisan Gawanda & Normal cookstove & 5.81 \\
& Cookstove with TTs & 4.56 \\
Tukibai Dhavlya Gawanda & Normal cookstove & 5.78 \\
Gulab Chander Bhagat & Cookstove with TTs & 4.39 \\
Hirabai Govinda Gawanda & Normal cookstove & 7.25 \\
& Cookstove with TTs & 5.56 \\
& Normal cookstove & 7.22 \\
Shevanta Dehu Bangare & Cookstove with TTs & 5.89 \\
& Normal cookstove & 9.08 \\
& Cookstove with TTs & 7.43 \\
& Normal cookstove & 9.39 \\
\hline & Cookstove with TTs & 7.38 \\
\hline
\end{tabular}

other tools required for agricultural and domestic activities. Recently, many of them have diversified their skills to lay tin roofs and build steel gates. Manufacturing of TT pack involves cutting, drilling, heating, twisting, and welding operations. Thus, the local blacksmiths who have welding and drilling machines can manufacture the TT pack. There is a traditional custom of buying and repairing the iron/steel tools from local blacksmiths. Thus, the manufacture and selling of the TT packs can be accommodated in the existing sustainable traditional business of the blacksmiths.

A blacksmith's work load is seasonal. He makes and repairs ploughs and sickles during monsoon for agricultural activities, while he makes axes and other tools in the winter season. During summer, he is engaged in house building activities that involve welding, tin/steel cutting, and drilling operations. Usually, a blacksmith has leisure time during monsoon season. Thus, the blacksmiths can allot more time to make TT packs during monsoon.

A manufacturing process to build the TT packs has been devised by interacting with two blacksmiths and one steel fabricator ${ }^{\mathrm{g}}$.

(1) A steel plate with thickness of 1.5 to $2 \mathrm{~mm}$ is cut to get small plates of required TT size.

(2) The plates are placed in the blacksmith's kiln to make them red hot.

(3) The red hot plate is held in a vise and twisted by a long lever with a groove to hold the plate. It is twisted by $60^{\circ}$ to $90^{\circ}$ in one go. It is then again placed in the kiln to heat. The whole process of twisting it to $180^{\circ}$ requires two to three steps. This is to ensure a smooth curve for the twisted tape. 
Table 9 Specifications of the cookstoves in Gawand wadi (refer to Figure 12 for notations)

\begin{tabular}{|c|c|c|c|c|c|c|c|c|c|c|c|}
\hline Type & $V\left(\mathrm{~cm}^{3}\right)$ & $g(\mathrm{~cm})$ & $h(\mathrm{~cm})$ & $i(\mathrm{~cm})$ & $m(\mathrm{~cm})$ & $a(\mathrm{~cm})$ & $b(\mathrm{~cm})$ & $h(\mathrm{~cm})$ & $I(\mathrm{~cm})$ & $k(\mathrm{~cm})$ & $o(\mathrm{~cm})$ \\
\hline $\begin{array}{l}\text { Two-pot } \\
\text { cook stove }\end{array}$ & $\begin{array}{l}9624 \pm \\
5240\end{array}$ & $\begin{array}{l}13.77 \pm \\
3.3\end{array}$ & $\begin{array}{l}13.75 \pm \\
3.3\end{array}$ & 0.00 & $\begin{array}{l}18.58 \pm \\
4.2\end{array}$ & $\begin{array}{l}54.58 \pm \\
13.5\end{array}$ & $\begin{array}{l}26.88 \pm \\
6.9\end{array}$ & $\begin{array}{l}5.96 \\
1.5\end{array}$ & $\begin{array}{l}13.67 \pm \\
4.8\end{array}$ & $\begin{array}{l}14.46 \pm \\
6\end{array}$ & $\begin{array}{l}5.82 \\
1.23\end{array}$ \\
\hline $\begin{array}{l}\text { Three-pot } \\
\text { cookstove }\end{array}$ & $\begin{array}{l}13152 \pm \\
7130\end{array}$ & $\begin{array}{l}13.72 \pm \\
3\end{array}$ & $13.8 \pm 3$ & $\begin{array}{l}10.98 \pm \\
2.7\end{array}$ & $\begin{array}{l}18.75 \pm \\
5.1\end{array}$ & $\begin{array}{l}57.11 \\
14.1\end{array}$ & $\begin{array}{l}26.98 \pm \\
5.7\end{array}$ & $\begin{array}{l}6.18 \pm \\
1.8\end{array}$ & $\begin{array}{l}14.16 \pm \\
5.4\end{array}$ & $\begin{array}{l}15.08 \pm \\
7.2\end{array}$ & $\begin{array}{l}6.41 \\
1.98\end{array}$ \\
\hline
\end{tabular}

(4) A hole is drilled in the TT to insert a steel rod (4 $\mathrm{mm}$ diameter).

(5) Finally, a TT pack is made by welding the rods together.

The present material cost is US\$0.5 per TT pack. By considering the manufacturing cost, transport cost to buy steel plate and rods, and the profit of blacksmith (US\$8 per day), the total cost comes to around US $\$ 1.25$ per TT pack. The technology is being disseminated with the help of two local volunteer organizations, Disha Kendra and Oak Vanaushadhi Kendra.

\section{Dissemination of the innovation}

As of now, 45 families from 11 different villages ${ }^{\mathrm{h}}$ have been using the TT packs in their cookstoves. Ten out of these families have been using this device for more than a year. Similar traditional cookstoves are found across the coastal belt of Maharashtra. Thus, the same innovation can be disseminated across the villages in this coastal region. For the other parts of rural India, the stove designs are much different, and there is a need to identify a context-specific intervention, which may not necessarily be a twisted tape.

\section{Conclusion}

The present study derives a novel bottom-up approach to develop or improve a rural/community technology by appreciation of wider aspects of the technologycommunity linkage, namely, people's priorities, people's desires behind improvement or development of technology, importance of studying and maintaining existing technology practises, availability of local resources to manufacture and operate the technology, and its commercial viability and sustainability. It enhances social efficiency of adoption of the technology by people. Overall, the approach mingles three aspects linked with rural/community technology.
(1) Social: This includes people's participation to set the goal behind the development of technology, appreciation of the existing context in terms of livelihood activities, local natural resources, and human skills.

(2) Technical: This includes the formulation of a procedure to measure the performance of the technology according to existing context, laboratory and field-level testing, feedback from the people, and further improvements in the technology.

(3) Commercial: Manufacturing and distribution through locally sustainable structure.

Retrofitting of the TT pack in the existing cookstoves in the village would save nearly $22 \%$ of human work hours and human energy involved in the firewood fetching activity. For an average family of six, women make 97 to 122 trips per year to the local forest to fetch firewood. These trips can be decreased by 21 to 27 . By considering an average duration of $4.5 \mathrm{~h} /$ trip, there can be an annual saving of 95 to 122 women work hours. The TT pack also decreases soot accumulation on the outer surface of pot by around $38 \%$. Based on the temperature variation graph of the water boiling test in the laboratory, the TT pack reduces the cooking time by around $18.5 \%$. For an average family of six, it saves $0.5 \mathrm{~h}$ daily and $182 \mathrm{~h}$ annually required for cooking preparations. Although the laboratory experiments showed that the optimal retrofitting of the twisted tapes improves combustion and thereby reduces indoor air pollution, it remains to measure the percentage reduction of healthdamaging emissions ${ }^{\mathrm{i}}$.

\section{Endnotes}

${ }^{\text {a }}$ Improved cookstove is generally regarded as a relative concept. Improved cookstoves may improve fuel efficiency, reduce indoor air pollution that causes

Table 10 Specifications of cookstove used for laboratory testing (refer to Figure 12 for notations)

\begin{tabular}{lccccccccc}
\hline $\begin{array}{l}\text { Hearth zone volume } \\
\left(\boldsymbol{V}, \mathbf{c m}^{3}\right)\end{array}$ & $\boldsymbol{g}(\mathrm{cm})$ & $\boldsymbol{h}(\mathrm{cm})$ & $\boldsymbol{m}(\mathrm{cm})$ & $\boldsymbol{a}(\mathrm{cm})$ & $\boldsymbol{b}(\mathrm{cm})$ & $\boldsymbol{h}(\mathrm{cm})$ & $\boldsymbol{I}(\mathrm{cm})$ & $\boldsymbol{k}(\mathrm{cm})$ & $\boldsymbol{o}(\mathrm{cm})$ \\
\hline 9,034 & 14.3 & 14.1 & 20.4 & 54 & 26.6 & 6.5 & 12.3 & 12 & 6.3 \\
\hline
\end{tabular}


Table 11 Specifications of the selected cookstoves for field level experimentation (refer to Figure 12 for notations)

\begin{tabular}{|c|c|c|c|c|c|c|c|c|c|c|c|c|}
\hline Households & Family size & $V\left(\mathrm{~cm}^{3}\right)$ & $g(\mathrm{~cm})$ & $h(\mathrm{~cm})$ & $i(\mathrm{~cm})$ & $m(\mathrm{~cm})$ & $a(\mathrm{~cm})$ & $b(\mathrm{~cm})$ & $h(\mathrm{~cm})$ & $I(\mathrm{~cm})$ & $k(\mathrm{~cm})$ & $o(\mathrm{~cm})$ \\
\hline Ambabai Kisan Gawanda & 3 & 12,019 & 14 & 14 & 11 & 19 & 57 & 27 & 6 & 14 & 12 & 6 \\
\hline Tukabai Dhavlya Gawanda & 4 & 7,060 & 13.5 & 12.5 & & 16 & 55 & 25 & 5 & 12 & 12 & 6 \\
\hline Gulab Chander Bhagat & 5 & 14,446 & 14 & 14 & 12.5 & 18 & 55 & 26 & 6 & 14.5 & 16.5 & 7 \\
\hline Hirabai Govinda Gawanda & 7 & 10,257 & 14 & 14 & & 20.5 & 58 & 25 & 7 & 13.5 & 15 & 5.5 \\
\hline Shevanta Dehu Bangare & 9 & 11,589 & 15 & 14.5 & & 17.5 & 58 & 29 & 6 & 15 & 17 & 7 \\
\hline Bhimabai Kalu Warghade & 14 & 14,943 & 15 & 14.5 & 10 & 19 & 68 & 29 & 6 & 15 & 16 & 7 \\
\hline
\end{tabular}

multiple health hazards, prevent fire hazards, reduce cooking time, or reduce green house gas emissions [56-58].

b It is a particulate matter especially black carbon.

c It was assumed that US $\$ 1$ is around 50 Indian Rupees.

$\mathrm{d}$ This is a pre-monsoon activity in which grass, tree branches, leaves, and cattle dung are burnt over around one-fifth part of the farm to prepare the land for sowing of paddy.

e Space heating is required during winter season to warm the house during night and early morning.

$\mathrm{f}$ The details of the thermo-chemical model of the traditional cookstove are not discussed in the present report and will be presented elsewhere.

g Madhukar Chavan from Kashele, Anil Jadhav from Kondivade, and Pankaj Gore from Vaingaon.

$\mathrm{h}$ These villages are Gawand wadi, Tepachi wadi, Waghai wadi, Kothimbe, Rajpe, Kalamb, Vare, Kondivade, Tamhanath wadi, Khandpa, and Dhare wadi located in Karjat block of Raigadh district of Maharashtra state.

${ }^{i}$ Major health-damaging emissions involve particulate matter, carbon monoxide, carcinogens such as benzo[a]pyrene, formaldehyde, nitrogen dioxide, and sulfur dioxide $[59,60]$.

\section{Appendices}

\section{Appendix 1}

Specifications of the traditional cookstoves in Gawand wadi

The specifications of the two-pot and three-pot stoves are shown in Tables 9, 10, and 11, and in Figures 12, 13 and 14.

The size of the cookstove usually increases with family size as shown in Figures 13 and 14.

\section{Appendix 2}

\section{Manufacturing process of the traditional cookstoves}

For the present exercise, the manufacturing process of the cookstoves was understood from two manufacturers in the village and also from the two potters from two different villages in Karjat block (Gajanan Kumbhar from village Sugve and Padma Kumbhar from village Shelu). The materials for the construction of a two-pot cookstove are approximately $30 \mathrm{~kg}$ clay, $2 \mathrm{~kg}$ rice husk, $2 \mathrm{~kg}$ ash, and $3 \mathrm{~kg}$ cattle dung. The soil found in the upper layer of paddy field is usually used to build the cookstoves. The process can be described in a step-wise fashion as follows:

(1) Small stones and larger particles are separated from the soil. This soil is then put in a wet bag for around 8 days.

(2) The soil is mixed with rice husk, ash, and cattle dung, and pressed with legs for around $20 \mathrm{~min}$ to make it a homogeneous mixture. It is believed that these added ingredients to the soil act as binding agents and increase the strength of the cookstove.

(3) The stove dimensions are drawn on the ground, and the stove is built on it by placing small pieces of mud one above the other. The potters also use

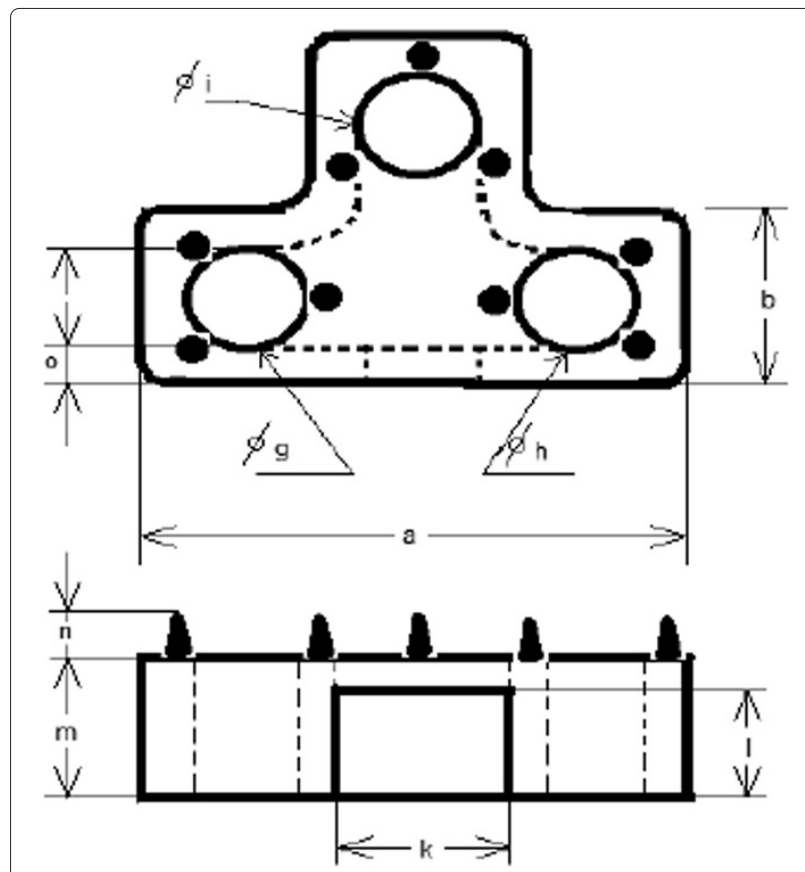

Figure 12 Traditional cookstove dimensions in Gawand wadi. Figure shows a schematic including top view and front view of a three-pot cookstove. The average specifications of all the two-pot and three-pot cookstoves in the village are listed in Table 4. 


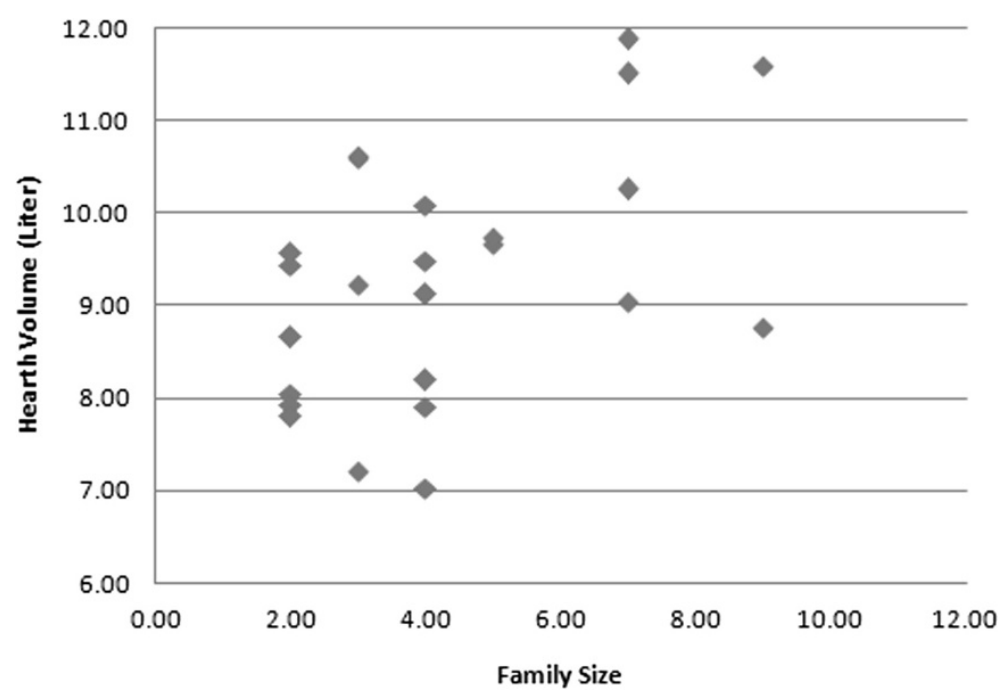

Figure 13 Variation of hearth volume of a two-pot stove (in Gawand wadi) with family size. Hearth volume of a cookstove is the total space available in a cookstove to carry out firewood combustion. It involves the volume of the hearth holes below each pot and the remaining cookstove volume inside the fuel input port. The present graph shows the variations of all two-pot cookstove volumes with respective family sizes.

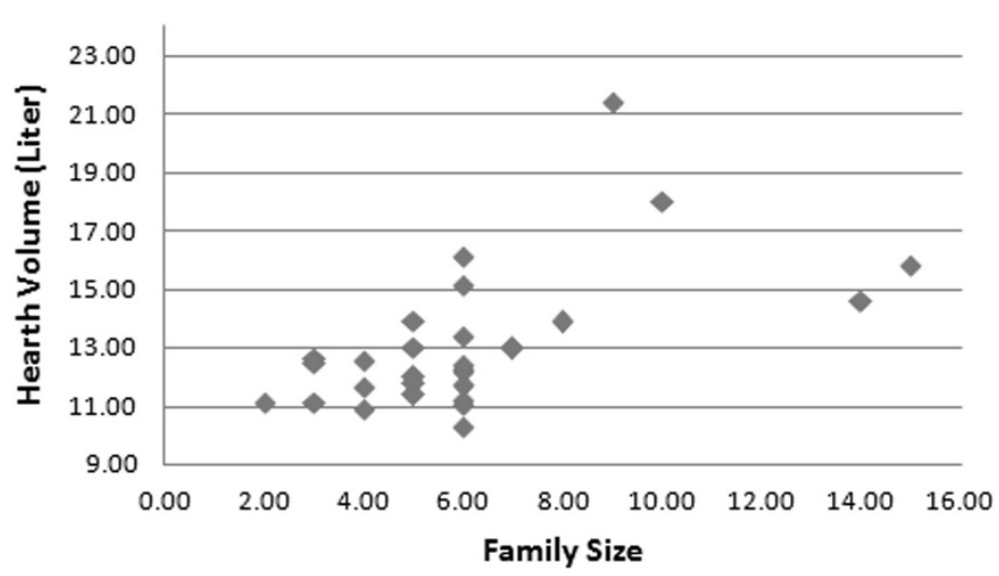

Figure 14 Variation of hearth volume with family size of three-pot stove in Gawand wadi. The present graph shows the variations of all three-pot cookstove volumes with respective family sizes.

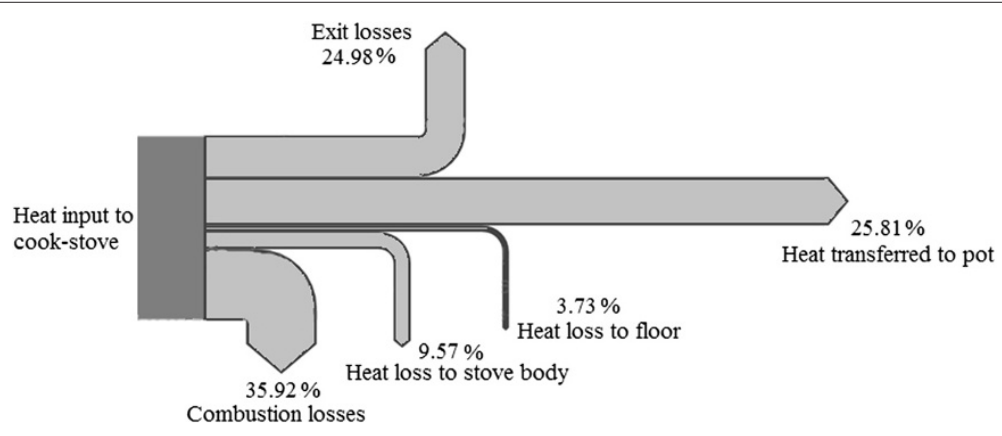

Figure 15 Heat flow diagram of the traditional cookstove. The Sankey diagram for the operation of the traditional cookstove. It shows that the key areas of improvement are increasing combustion efficiency and reduction of exit losses (or improvement of heat transfer to the pot bottom). 
wooden moulds to increase the rate of production of cookstoves. The process takes around $1 \mathrm{~h}$.

(4) Two days later, when the stove is partially dried, the opening for firewood feeding is carved.

(5) Finally, the stove is allowed to dry for 8 days before it can be used.

On an average, a potter builds two cookstoves per day. A two-pot cookstove is sold at the rate of USA $\$ 3$ per piece, and a three-pot cookstove is sold at the rate of US\$4 per piece.

\section{Appendix 3 \\ Heat flow diagram of cookstove}

Figure 15 shows the heat flow diagram of the traditional cookstove that was used for the laboratory tests.

\section{Abbreviations}

WBT: Water boiling test; KPT: Kitchen performance test; $\Pi$ : Twisted tape.

\section{Competing interests}

The authors declare that they have no competing interests.

\section{Authors' contributions}

$\mathrm{VHH}$ contributed in capacity development, carrying out field-level investigations, field tests, and report writing. He is thus the lead contributor to the paper. UVB and MS have contributed in providing guidelines to devise the methodology and providing inputs on the experiments and in the overall sense to structure the report. All authors read and approved the final manuscript.

\section{Authors' information}

$\mathrm{VHH}$ is a PhD research scholar. UVB and MS are professors and the PhD advisors of $\mathrm{VHH}$. $\mathrm{VHH}$ completed a dual degree (BTech + Mtech) in the Department of Mechanical Engineering at IIT Bombay in July 2007. Thereafter, he worked with Suzlon Energy Limited for a period of 6 months before joining CTARA for his doctoral research work. MS did his masters degree in the University of Illinois in 1988 and his Btech and PhD from IIT Bombay in 1986 and 1993. He was appointed as assistant professor at IIT Bombay in 1994. Since 2005, he has focused on rural drinking water as an area of research. Presently, he is a professor in the Department of Computer Science and Engineering at IIT Bombay and the current head of the Centre for Technology Alternatives for Rural Areas (CTARA). UVB obtained a bachelors in Mechanical Engineering from IIT Bombay in 1995 and obtained his Masters and PhD degrees from the University of Minnesota in 2000 and 2002, respectively. He was appointed as an assistant professor at the Department of Mechanical Engineering at IIT Bombay in 2004. Presently, he is an associate professor at IIT Bombay.

\section{Acknowledgements}

The authors are thankful to the people of the village Gawand wadi, especially to the women, for their participation and support throughout the research work.

\footnotetext{
Author details

${ }^{1}$ CTARA, Indian Institute of Technology Bombay, Mumbai, 400076, India. ${ }^{2}$ Department of Mechanical Engineering, Indian Institute of Technology Bombay, Powai, Mumbai, 400076, India. ${ }^{3}$ Department of Computer Science and Engineering, Indian Institute of Technology Bombay, Mumbai, 400076, India.

Received: 16 March 2013 Accepted: 25 July 2013

Published: 12 August 2013

\section{References}

1. Brown E (1996) Deconstructing development: alternative perspectives on the history of an idea. J Hist Geogr 22(3): 333-339

2. Smith KR (1989) Dialectics of improved stoves. Econ Polit Weekly 24(10): 517-522
}

3. Westhoff B (1995) One of the oldest technologies in the world - from the open hearth to the microwave. In: Westhoff B, Germann D (eds) Stove images: a documentation of improved and traditional stoves in Africa, Asia and Latin America 1995. Brandes and Apsel, Frankfurt

4. Sesan TA (2011) What's cooking? Participatory and market approaches to stove development in Nigeria and Kenya. Doctoral thesis, University of Nottingham

5. Crewe E (1997) The silent traditions of developing cooks. In: Grillo R, Stirrat R (eds) Discourses of development: anthropological perspectives. Berg, Oxford

6. Barnes DF, Openshaw K, Smith KR (1994) What makes people cook with improved biomass stoves? A comparative international review of stove programs. Technical report, World Bank Technical Paper Number 242, Energy Series, Washington DC: The World Bank

7. Sanchez T (2008) Lessons from project implementation on cook stoves and rural electrification, the practical action experience. Technical report, Practical Action, Rugby

8. Smith KR, Shuhua G, Kun H, Daxiong Q (1993) One hundred million improved cookstoves in China: How was it done? World Dev 21(6): $941-961$

9. Jagdish KS (2004) The development and dissemination of efficient domestic cook stoves and other devices in Karnataka. Curr Sci 87(7): 926-931

10. Krishna C (2000) Improved cook stoves; yet to be a success story. http://bioenergylists.org/files/IMPROVED_COOK_Stoves_Evaluation.pdf. Accessed 21 Feb 2012

11. Venkataraman C, Sagar A, Habib G, C NL, Smith K (2010) The Indian National Initiative for Advanced Biomass Cookstoves: the benefits of clean combustion. Energ Sus Dev 14: 63-72

12. Kishore V, Ramana P (2002) Improved cookstoves in rural India: how improved are they? A critique of the perceived benefits from the National Programme on Improved Chulhas (NPIC). Energ 27: 47-63

13. Bailis R, Cowan A, Berrueta V, Masera O (2009) Arresting the killer in the kitchen: the promises and pitfalls of commercializing improved cookstoves. World Dev 37(10): 1694-1705

14. Lim SS, Vos T, Flaxman AD, Danaei G (2013) A comparative risk assessment of burden of disease and injury attributable to 67 risk factors and risk factor clusters in 21 regions, 1990Ü2010: a systematic analysis for the global burden of disease study 2010. Lancet 380(9859): 2224-2260

15. Rai K, McDonald J (2009) Cookstoves and markets: experiences, successes and opportunities. Technical report, GVEP International, London

16. Dhoble R, Bairiganjan S (2009) Cooking practices and cook stoves field insights: a pilot study of user experience with traditional and improved cook stoves. Technical report, Centre for Development Finance, Institute for Financial Management and Research. Chennai, India

17. Smith KR (2010) What's cooking? A brief update. Energ Sus Dev 14 251-252

18. Sesan TA (2012) Whose priorities? Evaluating objectives of participatory development in the context of household energy projects in Africa. http://www.gbengasesan.com/temidocs/WhosePriorities.pdf. Accessed 23 Oct 2012

19. Rouse J (1999) Improved biomass cookstove programs: fundamental criteria for success. Masters thesis, The Centre for the Comparative Study of Culture, Development \& the Environment, The University of Sussex

20. Ergeneman A (2003) Dissemination of improved coosktoves in rural areas of developing world: recommendations for the Eritrea dissemination of improved stoves program. Technical report, Eritrea Energy Research and Training Center, Eritrea

21. Oakley P (1998) Strengthening people's participation in rural development. New Delhi, India: Society for Participatory Research in Asia, Occasional Paper Series No. 1

22. Pearse A, Stiefel M (1980) Inquiry into participation: a research approach Technical report, United Nations Research Institute for Social Development, Geneva

23. Westergaard K (1986) People's participation, local government and rural development: the case of West Bengal, India. CDR research report 8, Centre for Development Research, Copenhagen

24. Parfitt T (2004) The ambiguity of participation: a qualified defence of participatory development. Third World Q 25(3): 537-555 
25. Troncoso K, Castillo A, Masera O, Merino L (2007) Social perceptions about a technological innovation for fuelwood cooking: case study in Rural Mexico. Energ Policy 35: 2799-2811

26. Shrestha SK, Thapa R, Bajracharya K (2003) National improved cook stove dissemination in the mid-hills of Nepal, experiences, opportunities and lesson learnt. Technical report, The Asia Regional Cookstove Program Network, Yogyakarta, Indonesia

27. Sinha B (2002) The Indian stove programme: an insiders' view - the role of society, politics, economics and education. Boiling Point 48: $23-26$

28. Ruiz-Mercado I, Masera O, Zamora H, Smith KR (2011) Adoption and sustained use of improved cookstoves. Energ Policy 39: 7557-7566

29. Rouse J (2002) Community participation in household energy programmes: a case-study from India. Energ Sus Dev 6(2): 28-36

30. Quadir SA, Mathur S, Kandpal TC (1995) Barriers to dissemination of renewable energy technologies for cooking. Energ Policy 36(12): 1129-1132

31. Tata Energy Research Institute (1989) Evaluation of improved stoves in Tamil Nadu, Rajasthan and West Bengal. Technical report, Submitted to the Department of Non-conventional Energy Sources, New Delhi, Tata Energy Research Institute, New Delhi

32. Berruetaa VM, Edwardsb RD, Maserac OR (2008) Energy performance of wood-burning cookstoves in Michoacan, Mexico. Renew Energ 33: 859-870

33. Makonese T, Chikowore G, Annegarn HJ (2011) Potential and prospects of improved cookstoves (ICS) in Zimbabwe. Paper presented at domestic use of energy (DUE) conference, Cape Town, 11-13 April 2011

34. Bailis R, Ogle D, MacCarty N, Still D (2007) The water boiling test. Technical report, Shell Foundation. http://ehs.sph.berkeley.edu/hem/content/ WBT_Version_3.0_Jan2007a.pdf

35. Bailis R, Ogle D, MacCarty N, Still D (2004) The Water Boiling Test (WBT), version 1.5. Technical report, University of California-Berkeley

36. Volunteers in Technical Assistance InternationalStandards (1985) Testing the efficiency of wood burning cook stoves. Technical report, VITA, Virginia, USA

37. Chambers R (1994) The origins and practice of participatory rural appraisal. World Dev 22(7): 953-969

38. Date AW (1989) Energy utilization pattern of Shilarwadi. Indian J Rural Technol 1: 33-63

39. Reddy AKN (1982) Rural energy consumption patterns - a field study. Biomass 2: 255-280

40. National Sample Survey Organization (2010) Press note on income, expenditure and productive assets of farmer households (January-December 2003). http://pib.nic.in/release/rel_print_page1.asp? relid=14531. Accessed 2 Jan 2012

41. Arnstein SR (1969) A ladder of citizen participation. J Am I Plann 35(4): 216-224

42. Aref F, Redzuan M (2009) Assessing the level of community Participation as a component of community capacity building for tourism development. Eur J Soc Sci 8: 68-75

43. Google (2012) Maps. http://maps.google.com/. Accessed 20 March 2012

44. Lepeleire GD, Krishna Prasad K, Verhaart P, Visser P (1981) A woodstove compendium. Technical report, Wood burning stove group, Eindhoven University of Technology, Netherlands

45. Geller HS (1982) Cooking in the Ungra area: fuel efficiency, energy losses, and opportunities for reducing firewood consumption. Biomass 2(6): 83-101

46. Bhatt MS (1982) The efficiencies of firewood devices (open fire stoves, chulhas, and heaters). Indian Acad Sci 5(part 4): 327-342

47. Bhandari S, Gopi S, Date AW (1988) Investigation of CTARA wood-burning stove. Part 1. Experimental investigation. Sadhana 13(4): 271-293

48. Baldwin SF (1952) Biomass stoves: engineering design, development, and dissemination. Technical report, VITA, 1600 Wilson Boulevard, Suite 500, Arlington, Virgnia, 22209, USA

49. Food and Agriculture Organization of The United Nations (1993) Improved solid biomass burning cookstoves: a development manual. Technical report, Regional Wood Energy Development Programme In Asia, GCP/RAS/154/NET, Field Document No.44, Bangkok
50. Nuntadusit C, Waehahyee M, Bunyajitradulya A, Eiamsa-ard S (2012) Heat transfer enhancement by multiple swirling impinging jets with twisted-tape. Int Commun Heat Mass 39: 102-107

51. Kinsella C, Donnelly B, O'Donovan TS, Murray DB (2008) Heat transfer enhancement from a horizontal surface by impinging swirl jets. Paper presented at the 5th European thermal-sciences conference, The Netherlands, 18-22 May 2008

52. Guillaume DW, LaRue JC (1995) Combustion enhancement using induced swirl. Exp Fluids 20: 59-60

53. Benajes J, Molina S, Garcya JM, Riesco JM (2004) The effect of swirl on combustion and exhaust emissions in heavy-duty diesel engines. J. Automobile Eng 218: 1141-1148

54. Ramirez S, Dwivedi P, Bailis R, Ghilardi A (2012) Perceptions of stakeholders about nontraditional cookstoves in Honduras. Environ Res Lett 7(4): 2-11

55. Karve P (2005) A model for dissemination of improved biomass fuels and cooking devices through rural enterprises. Boiling Point 50: 26-28

56. The World Bank (2011) Household cookstoves, environment, health, and climate change: a new look at an old problem. Technical report, The World Bank, Washington, DC

57. A Volunteer Group of Foresters in Nepal (2013) Improved cooking stoves. http://www.forestrynepal.org/wiki/117. Accessed 8 May 2013

58. Wikipedia (2013) Cook stove. http://en.wikipedia.org/wiki/Cook_stove Accessed 8 May 2013

59. Bruce N, Perez-Padilla R, Albalak R (2002) The health effects of indoor air pollution exposure in developing countries. Technical report, World Health Organization Geneva, Switzerland

60. World Health Organization (2010) WHO guidelines for indoor air quality: selected pollutants. Technical report, World Health Organization, Regional Office for Europe, Copenhagen, Denmark

doi:10.1186/2192-0567-3-16

Cite this article as: Honkalaskar et al:: Development of a fuel efficient cookstove through a participatory bottom-up approach. Energy, Sustainability and Society 2013 3:16

\section{Submit your manuscript to a SpringerOpen ${ }^{\circ}$ journal and benefit from:}

- Convenient online submission

Rigorous peer review

- Immediate publication on acceptance

- Open access: articles freely available online

- High visibility within the field

- Retaining the copyright to your article

Submit your next manuscript at $>$ springeropen.com 